\title{
Appraisal of intra-reservoir barriers in the Permo-Triassic successions of the Central Persian Gulf, Offshore Iran
}

\author{
$\begin{array}{llll}\text { H. RAHIMPOUR-BONAB } & \text { A.H. ENAYATI-BIDGOLI A. NAVIDTALAB } & \text { H. MEHRABI }\end{array}$
}

School of Geology, College of Science, University of Tehran, Iran

Rahimpur-Bonab E-mail: hrahimpor@gmail.com Enayati-Bidgoli E-mail: a.h.enayati@ut.ac.ir Navidtalab Email: navidtalab@gmail.com Mehrabi E-mail: hamze.mehrabi@khayam.ut.ac.ir

\begin{abstract}
Owing to their tightness, intra reservoir barriers have the potential to prevent homogenization of reservoir fluids and so cause compartmentalization. Identification of these barriers is an important step during reservoir evaluation. In order to achieve this, three main approaches: i) detailed petrographic and core analysis, ii) petrophysical studies (flow unit concept) and iii) geochemical analysis (strontium residual salt analysis) were applied systematically in the Permo-Triassic carbonate reservoirs (Dalan and Kangan formations) of a supergiant gas reservoir located in the Central Persian Gulf. Integration of these approaches has led to a full clarification of the intra reservoir barriers. Petrographic examinations revealed the potential stratigraphic barriers to fluids flow created by various depositional/ diagenetic characteristics. Petrophysical data such as poroperm values, pore throat size distribution and scanning electron microscopy (SEM) analysis were used to differentiate the reservoir flow units from non-reservoir rock. According to different trends in $87 \mathrm{Sr} / 86 \mathrm{Sr}$ ratios of residual salts, the existence of flow barriers was evaluated and proved. Finally, by integrating these approaches, three intra reservoir barriers were introduced in the studied reservoir interval. These intra reservoir barriers are depositional and diagenetic in nature and are located in stratal positions with sequence stratigraphic significance. The possibility of reservoir compartmentalization was evaluated in the studied wells, and then their existence was predicted at the adjacent fields. As shown in this study, integration of petrographic examinations with flow unit determination in a sequence stratigraphic framework has the potential for recognizing intra reservoir barriers and predicting compartmentalization of the studied Permo-Triassic reservoirs.
\end{abstract}

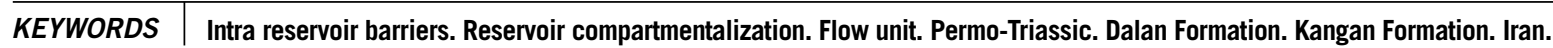

\section{INTRODUCTION}

Reservoirs which were created in a wide range of depositional systems and which have undergone by complex diagenetic overprints are often compartmentalized. Reservoir compartmentalization is defined as the segregation of a hydrocarbon accumulation into several individual fluid/pressure compartments. It occurs when the reservoir fluids are separated into different parts across impermeable boundaries such as faults or cemented stratigraphic horizons (Jolley et al., 2010). Several studies of both carbonate and siliciclastic reservoirs have shown that reservoir compartmentalization is a common phenomenon controlled by a variety of geological factors such as sedimentology, diagenesis, stratigraphy and/or tectonism at various scales (e.g. Ortoleva, 1994, Funayama and Hanor, 1995; Smalley et al., 1995; Mearns and McBride, 1999; Walgenwitz et al., 2001; Woule Ebongue et al., 2005, Rahimpour-Bonab, 2007, Jolley et al., 2010; Wonham et al., 2010). 
A compartment is a body of rock with relatively good hydraulic communication and porosity, which is surrounded by low permeability rock. Low permeability barriers can subdivide a reservoir body into several compartments between which, reservoir fluids are unable to flow for long periods of geological time (Slatt and Galloway, 1992; Ortoleva, 1994). These low permeability Intra Reservoir Barriers (IRBs) are parts of the reservoir that are not able to produce hydrocarbon at economic rates (Gaynor and Sneider, 1992). The degree of reservoir compartmentalization usually has an influence on the estimation of productive volume (Jolley et al., 2010) and should be taken into account for reservoir modeling, simulation studies, development planning, analysis of fluids contacts, and well testing.

The South Pars Gas Field along with its southern extension in the Qatari territory (North Field) is located in the Persian Gulf (Fig. 1). It is the world's largest gas reservoir (Insalaco et al., 2006). In this area, the Permian-Triassic Dalan and Kangan formations and their stratigraphic equivalent in the trucial countries (Khuff Fm.; Fig. 2) contain extensive natural gas reserves (Kashfi, 1992; Aali et al., 2006; Alsharhan, 2006). Lithologically, this interval is a mixture of dolostones, limestones and anhydrite. This variable lithology together with different sedimentary facies and various diagenetic processes (with positive or negative impacts on reservoir/flow quality) cause the reservoir to be extremely heterogeneous from micro to mega scales. Thus, the studied interval is a complex package composed of various impermeable or low permeability units with different sedimentary, diagenetic or stratigraphic genesis. Permeability reducing characteristics include anhydritic intercalations, increased mud content or strong cementation/compaction. The combination of these heterogeneities caused interesting compartmentalization of the reservoir from micro- to field scale.

In this study, our attempt is to discriminate IRBs within the Dalan and Kangan formations and to evaluate compartmentalization of the reservoir by integrating the results of petrographic studies (core descriptions and thin section), petrophysical evaluations and geochemical analyses (87Sr/86Sr ratios in residual salts). The Strontium Residual Salt Analysis (Sr-RSA) is a useful tool for the study of reservoir compartments and is routinely used by many researchers (e.g. Smalley et al., 1995; Mearns and McBride, 1999; Rahimpour-Bonab, 2007). Finally, the IRBs and compartments are evaluated and distinguished in other wells of the South Pars Field, neighboring Golshan Gas Field and even in other parts of the

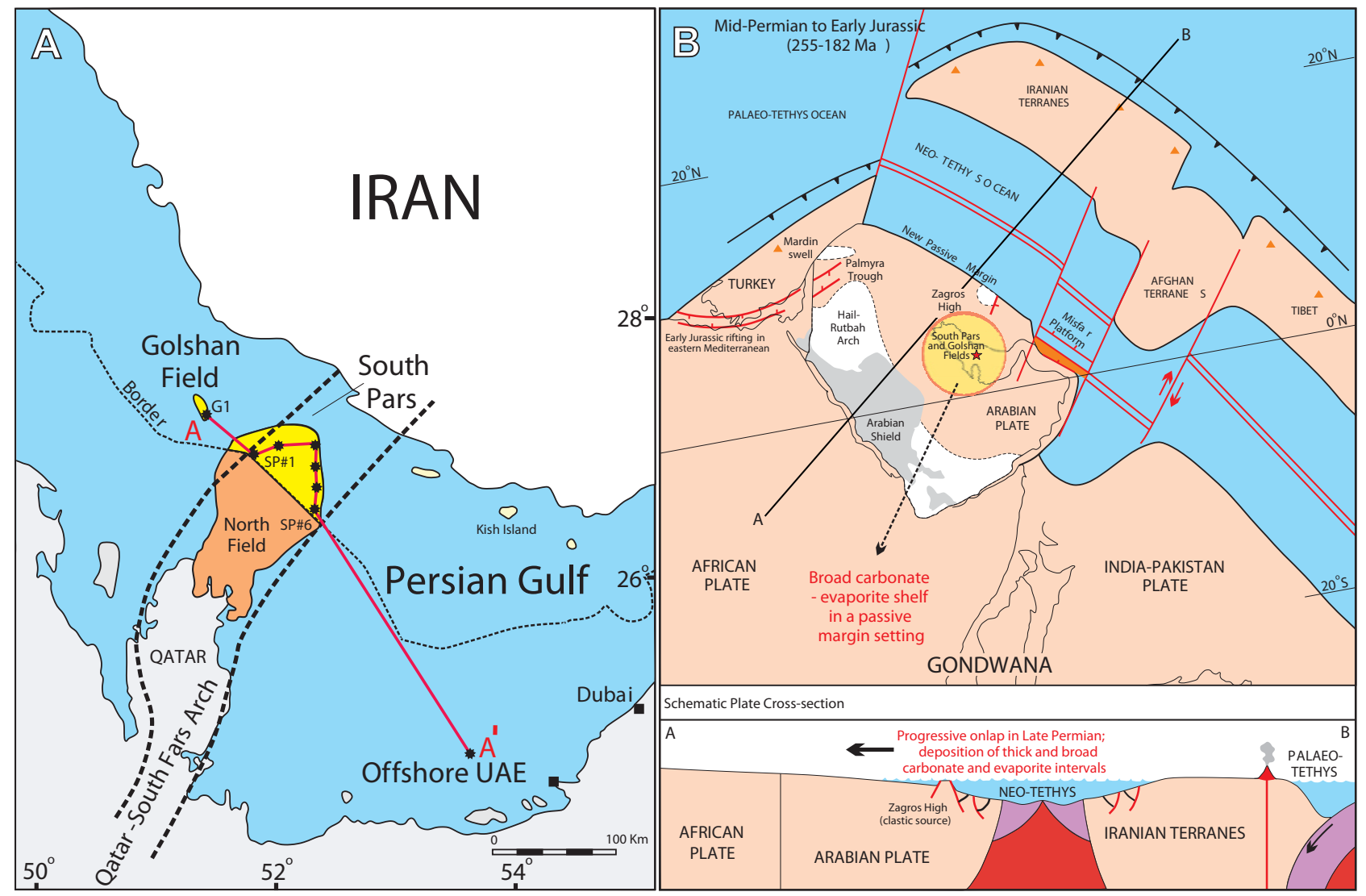

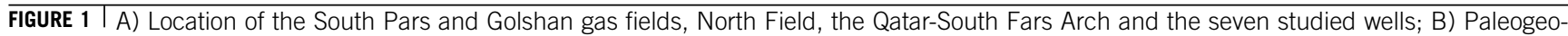
graphic and plate tectonic reconstruction of the Arabian Plate during deposition of the Dalan-Kangan (Khuff) Formations (modified from Sharland et al., 2001). 
Persian Gulf basin such as offshore United Arab Emirates (UAE; see A-A' section in Fig. 1A).

\section{GEOLOGICAL SETTING AND STRATIGRAPHY}

The supergiant South Pars Gas Field and its southern sector (North Field) are located on the enormous NNE-SSW trending Qatar-South Fars arch (Q-SF arch; Figs. 1A; 2). The Q-SF arch is placed in the interior of the Arabian Plate and extends to the Zagros Fold Belt in the north and northeast (Alsharhan and Nairn, 1997; Konert et al., 2001; Ziegler, 2001; Bashari, 2005; Konyuhov and Maleki, 2006; Perotti et al., 2011). This arch is a major regional anticline that extends through the central Persian Gulf and warped the sedimentary cover of the Arabian Platform (Perotti et al., 2011; Figs. 1A; 2). During the Paleozoic, the Q-SF arch was a block-faulted NNE-trending horst that began to subside progressively during the Jurassic (Saint-Marc, 1978).
The thickness of the sedimentary record covering structures such as the Q-SF arch varies considerably due to the Hercynian upwarping during the late Paleozoic (Alsharhan and Nairn, 2003; Fig. 2A). During the Late Permian-Early Triassic, this arch may have been a positive structure that led to more abundant deposition of high energy shallow marine carbonates (widespread oolitic/bioclastic shoals) in this area than over adjacent areas.

Deposition of Permian-Triassic shallow marine carbonates and evaporites was initiated by an extensive marine transgression on the Arabian Plate during the late Permian. This transgression was related to rifting across the Zagros that led to the opening of the Neotethys Ocean and creation of a passive margin in the northeastern part of the Arabian Plate in 182-255Ma (Pillevuit, 1993; Edgell, 1996; Sharland et al., 2001; Alsharhan and Nairn, 2003; Fig. 1B). These widespread carbonate-evaporite intervals were deposited as a blanket within which some individual

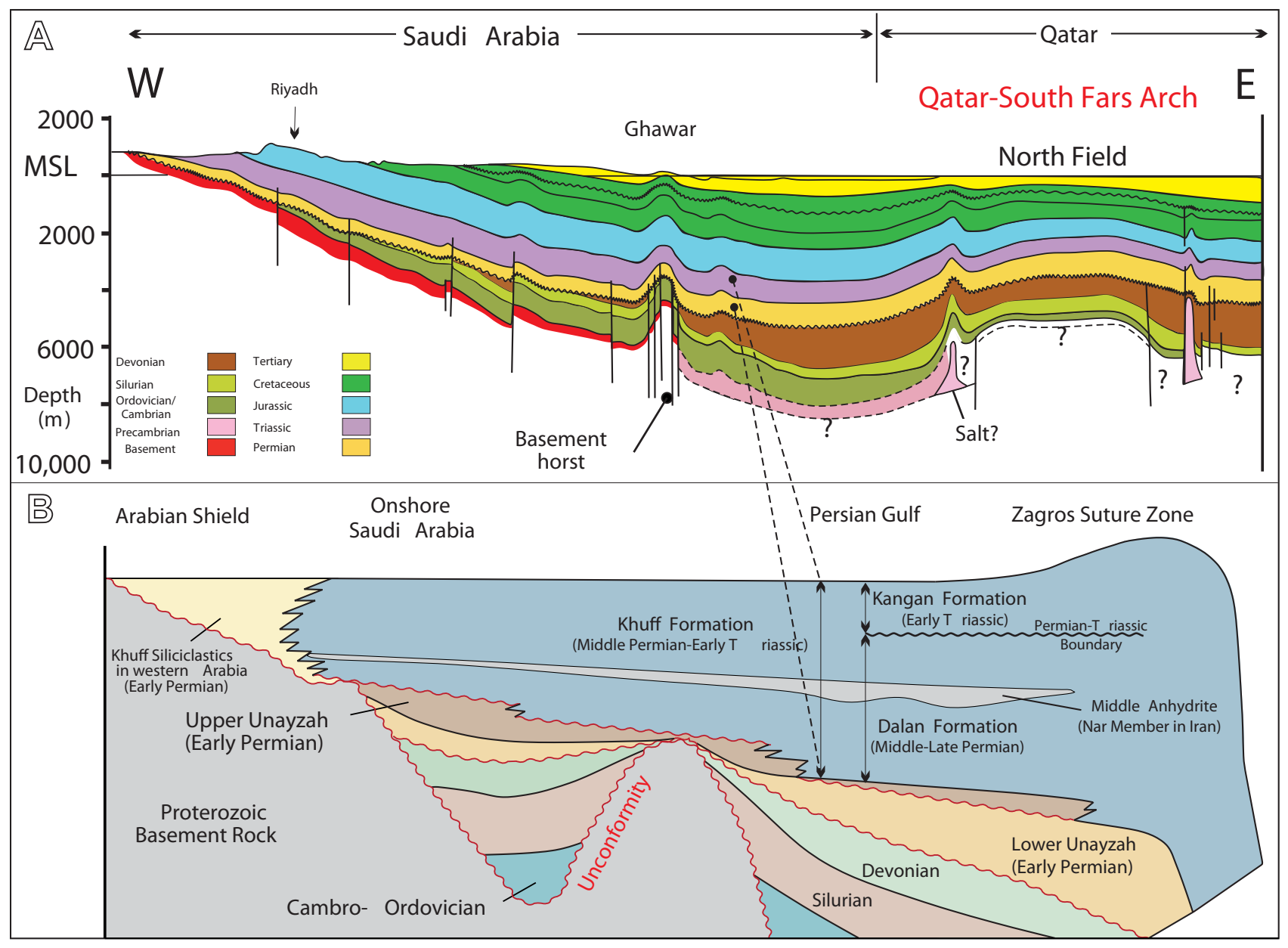

FIGURE 2 A) A cross-section of the Phanerozoic sedimentary cover overlying the Arabian Plate from the Arabian Shield to the Central Persian Gulf (the Qatar-South Fars Arch; modified from Afifi, 2005); B) A conceptual section of the Khuff Formation, its equivalents (the Dalan and Kangan Formations) in the Iranian territory, and lateral lithological changes from the Arabian Shield to the Persian Gulf and Zagros Suture Zone (modified from Strohmenger et al., 2002; Alsharhan, 2006). 
horizons are correlatable over wide distances throughout the Persian Gulf basin and adjacent areas (Fig. 2A).

In the South Pars Field, gas is mainly accumulated in the Permo-Triassic Dalan-Kangan formations (Dehram reservoirs). These units host several giant and supergiant natural gas reservoirs in the Persian Gulf (Kashfi, 1992; Aali et al., 2006). The Dalan Fm. is stratigraphically subdivided into three members including the lower Dalan, the Nar evaporite and the upper Dalan (Edgell, 1977; Fig. 2B; 3B). The upper Dalan has great reservoir potential and is further subdivided into two reservoir units: K4 (limestone-dolostone) and K3 (mainly dolostone to dolomitic limestone with some anhydritic intercalations; Fig.3B). The early Triassic Kangan Fm. (Szabo and Kheradpir, 1978) overlies the Dalan Fm. above the well-known and important Permo-Triassic disconformity (Heydari et al., 2001; Rahimpour-Bonab et al., 2009; Tavakoli and Rahimpour-Bonab, 2012) and terminates to the Dashtak Fm. (Fig. 2B; 3A). The Kangan Fm. comprises two reservoir units: K2 (limestone-dolostone and anhydrite) and K1 (anhydritic dolostone, dolostone and limestone; Fig. 3B). The K2, K3 and K4 reservoir units (upper Dalan and lower Kangan) were the focus of this study.

\section{MATERIALS AND METHODS}

This study examined more than 1500 meters of cores taken from the Permo-Triassic rock formations in seven exploration wells drilled in the South Pars and Golshan fields. In order to construct a framework for correlation of flow units and IRBs, the depositional sequences were distinguished. Petrographic studies were performed on core samples and thin sections for analyzing the depositional facies, diagenetic features and reservoir properties. Thin sections were stained with Alizarin Red S for discriminating calcite and dolomite minerals and samples were impregnated with blue died epoxy resin before thin sectioning for investigating pores types and their connectivity. Measured porosity-permeability data in cored intervals as well as poroperm

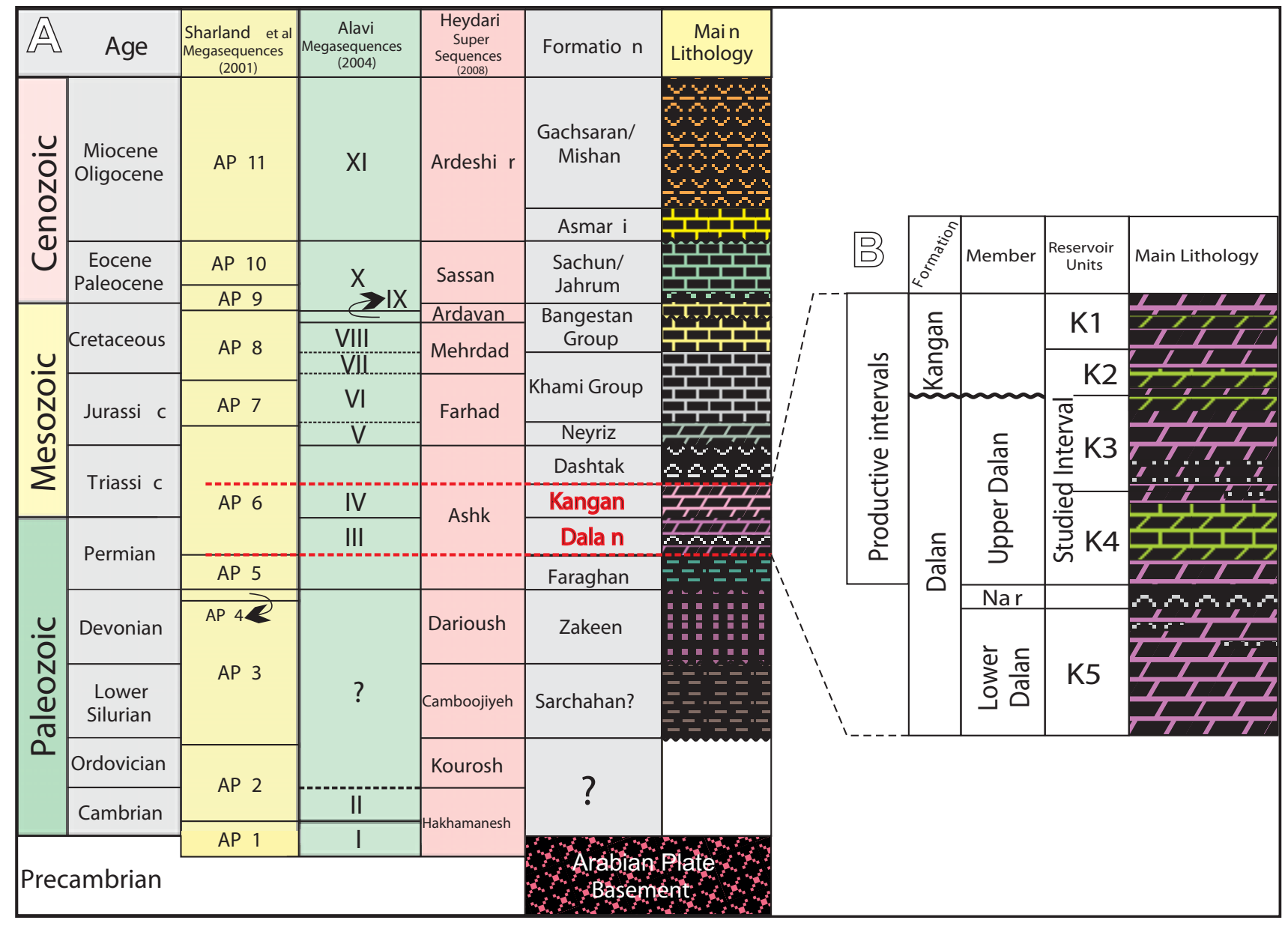

\begin{tabular}{l|l|l}
\hline FIGURE 3 & A) The stratigraphic column of the South Pars field and the position of the Dalan/Kangan formations in the defined mega/supersequences
\end{tabular} of the Arabian Plate and the Zagros basin (Sharland et al., 2001; Alavi, 2004; Heydari, 2008); B) Productive intervals in the South Pars field including Dalan and Kangan Formations. The studied interval consists of the K2, K3 and K4 reservoir units. 
deduced from log data were used for un-cored parts. Pore throat size distribution curves obtained from Mercury $(\mathrm{Hg})$ injection analyses were also applied in order to evaluate the ability of pore systems to conduct fluids (Martin et al., 1997; Gunter et al., 1997; Hartmann and Beaumont, 1999; Aguilera, 2004; Gomes et al., 2008). Pore structure was evaluated using Scanning Electron Microscope (SEM) microphotographs. In addition, various wireline logs including gamma-ray, density and Formation MicroImager (FMI) and interpreted lithology ratios were available. In order to determine reservoir unit connectivity and to evaluate flow barrier presence, the $87 \mathrm{Sr} / 86 \mathrm{Sr}$ ratios of residual salts $(\mathrm{Sr}-$ RSA; Rahimpour-Bonab, 2007) were applied.

\section{PETROGRAPHIC STUDIES AND POTENTIAL STRATIGRAPHIC BARRIERS (PSB)}

In carbonate reservoirs, flow characteristics reflect the porosity and permeability characteristics of the rock which are the result of a combination of depositional and diagenetic processes. Depositional processes control the original pore size distribution and the geometry of facies units. Diagenetic overprints modify the primary pore size distribution and control the final productivity of each depositional facies (Lucia, 1992, 1995, 2007). Analysis of facies and diagenesis is therefore of fundamental importance in the prediction of reservoir quality distribution within the studied intervals and also provides a means of identifying impermeable barriers associated with stratigraphic horizons, that may result in reservoir compartmentalization.

\section{Facies controls on reservoir quality}

Facies analysis was based on the description of primary rock properties such as grain types, grain size, sedimentary structures and color (Table I, Electronic Appendix available at www. geologica-acta.com) in the studied wells. Eleven depositional facies (microfacies) and four facies associations were defined. Each facies (association) has a primary potential for creation of either permeable, low permeability, and/or impermeable units based on its characteristics (Table I). The reservoir quality of facies and facies associations depends on depositional properties including mineralogy, constituent components and textural characteristics. Based on facies types and associations, the depositional model of the upper Dalan-lower Kangan formations in the South Pars Gas Field has been defined as a homoclinal ramp or epeiric platform (Szabo and Kheradpir, 1978; Kashfi, 1992; Insalaco et al., 2006; Rahimpour-Bonab et al., 2009; Esrafili-Dizaji and RahimpourBonab, 2009; Rahimpour-Bonab et al., 2010). Abundance of landward facies and scarcity of off-shoal facies (the deeper parts of mid ramp and outer ramp settings) indicate that the upper Dalan-lower Kangan formations were deposited over the shallow parts of a ramp. Depositional facies are mainly interpreted as shoal deposits overlain by prograding peritidal and lagoonal facies. Originally, good reservoir quality (high poroperm values) is mainly developed in the high energy shoal facies in comparison with the mud-dominated lagoon and off-shoal facies (Fig. 4D, $\mathrm{G}, \mathrm{L})$. Dolomitic mud-dominated textures with different types of anhydrite cements (laminated/layered, nodular and patchy) are the main rock fabrics in peritidal facies (Fig. 4A). The laminated/ layered anhydrite can act as an effective reservoir seal (Lucia, 1992; Ahr, 2008). The sealing potential of these peritidal (mainly anhydritic), lagoonal and off-shoal (mud-dominated) facies is high and they can act as stratigraphic barriers at different scales (from well bore to inter-well and even at field scale).

\section{Diagenetic processes and their controls}

In the upper Dalan and lower Kangan formations, various diagenetic processes have modified the primary reservoir characteristics of the depositional facies.

Meteoric dissolution of unstable aragonitic allochems in the oolitic/bioclastic sand shoals during the highstands was responsible for creating porosity, rearrangement of pore types (from interparticle to vuggy and moldic types) and increasing permeability (Fig. 4H, K). Seepage-reflux dolomitization (Rahimpour-Bonab et al., 2010), including fabric retentive and fabric destructive types (Fig. 4E, I, M) also created more uniform pore networks and sometimes larger pore spaces with associated higher permeability (Fig. 4D, E, G, I, L, M). Sometimes, nonreservoir depositional facies change into permeable ones due to diagenetic overprints and/or the generation of open fractures (Fig. 4B).

On the contrary, carbonate cementation (marine, meteoric and/or burial types; Fig. 4G, H, J, K), anhydrite cementation and replacement (Fig. 4A, B, E, K) and mechanical/chemical compaction (stylolitization; Fig. 4C, G, L) have reduced the reservoir quality. For example, reservoir quality has been decreased due to calcite and anhydrite cementation in shoal facies. The interparticle and vuggy pore spaces have been plugged by different types of cement (Fig. 4G and J, H and K). Macro and micro-stylolites are the result of chemical compaction in muddominated facies creating tight units and reducing poroperm values (Nelson, 1981; Dickson and Saller, 1995; Fig. 4C, L). Flow baffles and barriers in carbonate reservoirs of the Middle East are commonly the result of compaction (Ahr, 2008). Chemically compacted intervals recognized in wells are considered as likely indicators of IRBs as suggested by Ehrenberg (2006).

Other types of diagenetic processes such as calcite recrystallization or neomorphism (Fig. 4F, N) can also reduce reservoir quality. Generally, recrystallization reduces the poroperm values because the neomorphic microspars (Fig. 4F, $\mathrm{N})$ tend to fill pore space and reduce permeability (Ahr, 2008). The main depositional facies, diagenetic features and their effects on reservoir quality in the studied reservoirs are summarized in Figure 4 (see Esrafili-Dizaji and Rahimpour-Bonab, 2009; Rahimpour-Bonab et al., 2010; Tavakoli et al., 2011 for further information). 

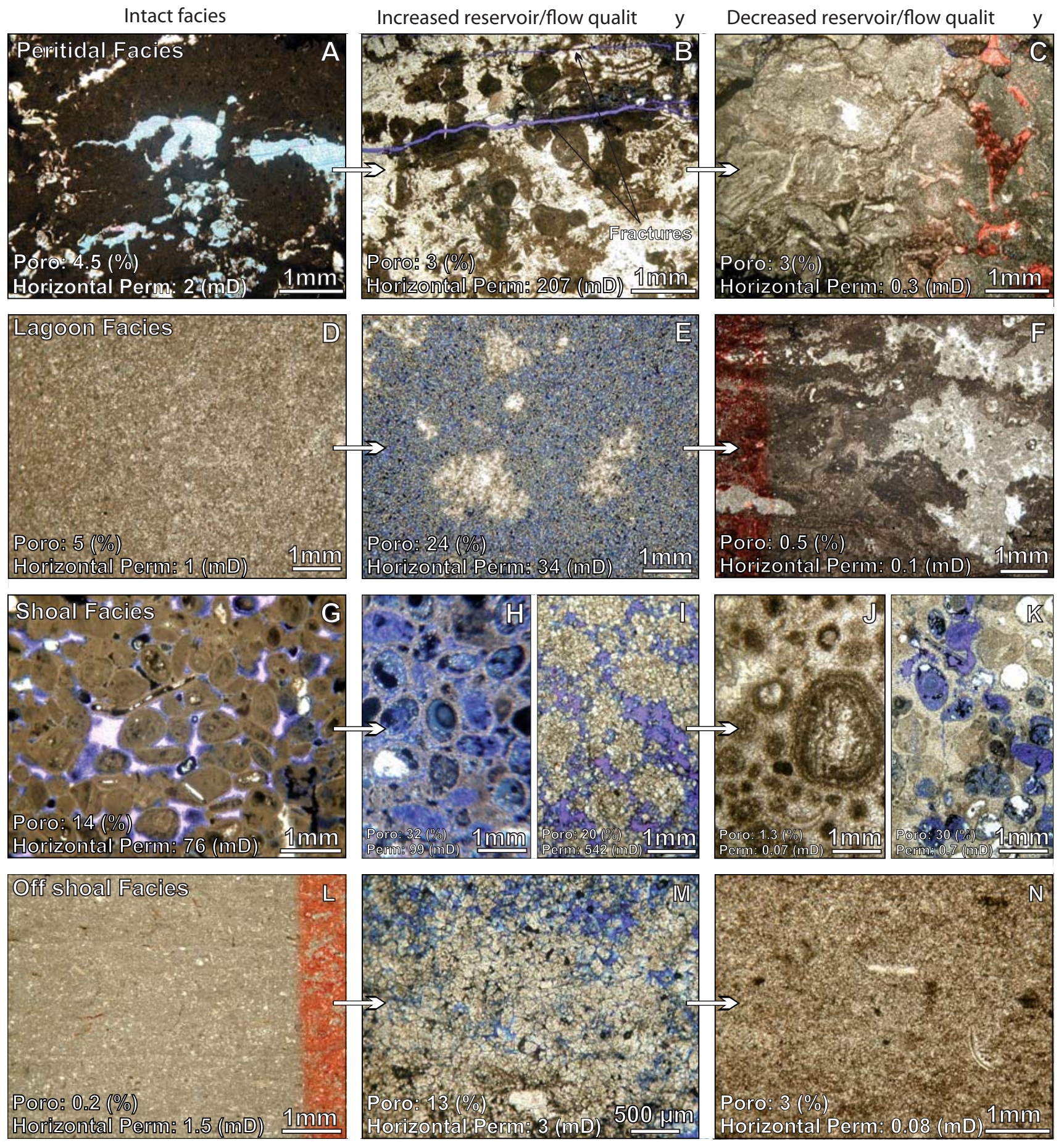

FIGURE 4 This plate is a quick look illustration to compare poroperm values related to preliminary depositional facies and their counterparts affected by positive or negative diagenetic processes in the well SP\#2. A-C) Peritidal facies: A) intact with low poroperm values (Depth 900.2m); B) permeability increased by fracturing (Depth 876.8m); C) decreased poroperm values due to stylolitization (Depth 838.7m). D-F) Lagoon facies: D) original with low poroperm values (Depth $882.5 \mathrm{~m}$ ); E) very good reservoir facies owing to dolomitization, despite some anhydritic patches (Depth $860.6 \mathrm{~m}$ ); F) a dense and tight facies created by chemical compaction and micrite recrystallization (Depth $1030.4 \mathrm{~m}$ ). G-K) Shoal facies: G) intact with very good poroperm values (Depth $856.4 \mathrm{~m}$ ); $\mathrm{H}-\mathrm{I}$ ) poroperm values increased by meteoric dissolution and dolomitization (Depths 986.3 and $815 \mathrm{~m}$ ); J-K) very weak reservoir facies produced by meteoric and shallow burial calcite cementation and pore- filling anhydrite (Depths 835.7 and $977.7 \mathrm{~m}$ ). L-N) Off-shoal facies: L) original with weak reservoir quality (Depth $1022.9 \mathrm{~m}$ ); M) good reservoir facies created by dolomitization (Depth $825.5 \mathrm{~m}$ ); N) a poor reservoir quality specimen because of micrite recrystallization (Depth $823 \mathrm{~m}$ ). 


\section{Sequence stratigraphy}

Depositional sequence recognition provides a framework for understanding the spatial organization of facies associations and IRBs especially those associated with horizons with stratigraphic significance. Sequence stratigraphy provides a genetic framework for correlation and prediction of vertical and lateral facies changes and associated changes in reservoir quality (Posamentier and Vail, 1988; Van Wagoner et al., 1990; Posamentier and Allen, 1999; Plint and Nummedal, 2000; Ahr, 2008).

In this study, construction of a sequence stratigraphic framework for the K2, K3 and K4 units of Dehram reservoirs, has been carried out using various data including facies analysis, log data (especially density and gamma-ray logs) and diagenetic features (e.g. meteoric dissolution and early evaporite precipitation).

Three third order sequences were identified and closely correlated between the studied wells in order to provide a framework for geologically-based reservoir modeling. This framework was used for the correlation of defined flow units and some specific IRBs (Fig. 5). The Permian-Triassic Boundary (PTB) is a major sequence stratigraphic boundary in the studied intervals (between $\mathrm{K} 3$ and $\mathrm{K} 2$ units) previously studied by many researchers (e.g. Heydari et al., 2001; Rahimpour-Bonab et al., 2009; Tavakoli and Rahimpour-Bonab, 2012). Marine erosion, meteoric dissolution and calcite cementation as well as anhydrite plugging in the upper part of the $\mathrm{K} 3$ reservoir unit are all diagenetic features related to the PTB (Rahimpour-Bonab et al., 2009). Diagenesis related to the PTB plays a key role in controlling the reservoir quality of the units below the PTB. Above the PTB, transgressive, mud-dominated deposits (off-shoal or thrombolitic facies) have very low reservoir quality (Fig. 5).

\section{Potential stratigraphic barriers based on petrography}

Well SP\#2 (Figs. 1; 5) has a relatively complete set of data including Conventional Core Analysis (CCAL), Special Core Analysis (SCAL), SEM, FMI and especially Sr-RSA. A 75m uncored interval in this well (the lower parts of K3) is observed in neighboring well $\mathrm{SP} 33$ based on sequence stratigraphic correlation.

In the SP\#2 well, three major Potential Stratigraphic Barriers (PSBs) were determined based on petrographic properties such as: i) mud-dominated fabrics; ii) impermeable and dense lithologies (anhydrite); iii) pervasive cements (i.e. pore-filling anhydrite, meteoric/marine carbonate cements); iv) recrystallization or v) stylolitization, (Fig. 5). The petrographic characteristics of each PBS are defined in detail below:

PSB1 (800 to 804m in well SP\#2): consists of tight anhydritic dolostones in which shoal and lagoonal facies are the major components and grainstone and wackestone are predominant fabrics. Fabric retentive dolomitization and anhydrite cementation (anhydrite plugging in vuggy/interparticle pores) are the main diagenetic features in this unit and pervasively occlude the pore network (Fig. 4B). In the SP\#3 well, PSB1 consists of lagoonal and peritidal facies that are strongly cemented by anhydrite. PSB1 is representative of the late Highstand Systems Tract (HST) of sequence SQ3 and is located below the basal anhydrite in the K1 reservoir unit.

PSB2 (837 to 846m in well SP\#2; Fig. 5): consists of dense lagoonal, peritidal (thrombolitic) and minor shoal facies with limestone lithology. The porosity has been infilled by anhydrite and calcite (meteoric and microspar) cements. This unit is located in the early Transgressive Systems Tract (TST) of sequence SQ3, just above the Permo-Triassic boundary and is considered to be a flow barrier due to the predominance of mud-dominated facies and some highly cemented shoal facies. The main diagenetic features are anhydrite cementation and stylolites. The absence of thrombolitic facies in the SP\#3 well is due to the deeper water depositional setting of this well in comparison to the SP\#2 well. The thrombolitic unit is not uniformly distributed at the scale of the field.

PSB3: In the SP\#2 well, no core was available from this interval (923 to $958 \mathrm{~m})$ and wireline logs are the only available data. The gamma ray log shows low and uniform values in this interval (Fig. 5). While, the density log shows higher values in the upper part of this interval indicating the presence of dense lithologies such as anhydrite and dolomite or very compacted limestone. The presence of limestone lithology and horizontal stylolites are indicated by density and FMI logs in this interval (Fig. 5). This strongly compacted (barrier) unit has formed by pressuresolution. In such stylolitized interval with residual hydrocarbon concentration along the stylolites, vertical permeability is more significantly affected than horizontal permeability (Nelson, 1981; Koepnick, 1987).

Study of core from the K3 unit indicate that this interval (PSB3) is dominated by lagoonal and peritidal facies comprising anhydritic dolostone and limestone lithologies in the SP\#3 well. The main diagenetic features are early dolomitization (dolomicrite), anhydrite cementation, horizontal stylolitization and micrite recrystallization. The non-tectonic genesis of these stylolites is reflected by their position parallel to the depositional bedding (e.g. Andrews and Railsback, 1997). Preferential development of abundant stylolites in mud-dominated units has also been reported in the Khuff B reservoir unit of Saudi Arabia (Hassan, 2007). The PSB3 unit is interpreted to be TST of sequence SQ2. The lower parts of K3 comprise in part tight limestone-dolostone successions (PSB3) which extend laterally between the two studied wells and have high sealing potential. The stratigraphic component of the seal consists of a single, approximately uniform lithologic unit which is compacted or cemented preferentially due to its original chemistry or texture; the diagenetic components of the seal corresponds to the abundant 
development of layered internal structures such as stylolites, clay seams and cementation/compaction alternations (Ortoleva, 1994).

There is a relatively thick mud dominated unit including offshoal facies with a mainly occluded pore system in the upper parts of the K3 reservoir unit of SP\#2 well (Fig. 5) but this interval cannot be considered as a barrier unit due to the presence of micro fractures (Fig. 6).

\section{FLOW UNIT DETERMINATION}

The upper Dalan-lower Kangan reservoir can be divided into several units with different reservoir/flow quality. The results of SEM, pore type, and pore throat (pore throat: port; Martin et al., 1997; Gunter et al., 1997; Hartmann and Beaumont, 1999; Aguilera, 2004; Gomes et al., 2008) size analysis (Mercury Injection Capillary Pressure, MICP) help to define geologicalpetrophysical flow units as well as the barrier units that are responsible for reservoir compartmentalization.

Ebanks (1987) defined the basic concepts of flow units as a volume of rock that can be differentiated from the others based on its geological and petrophysical characteristics affecting the fluid flow properties. Flow units subdivide the reservoir volume into geo-bodies which help in reservoir modeling and flow simulation (Bhattacharya et al., 2008).

Gunter et al. (1997) presented a graphical method for quantifying the flow units according to the geological framework, petrophysical rock/pore types, flow and storage capacities (Kh and $\Phi$, respectively), and reservoir process speed $(\mathrm{K} / \Phi)$. In this study, the minimum numbers of static flow units have been determined by using the static reservoir rock properties such as core poroperm values.

First, a Stratigraphic Modified Lorenz Plot (SMLP) was constructed using cumulative flow capacity $\left(\mathrm{Kh}_{\text {cum }}\right)$ and cumulative storage capacity $\left(\Phi \mathrm{h}_{\text {cum }} ;\right.$ Fig. $\left.7 \mathrm{~A}\right)$. The flow capacity $(\mathrm{Kh})$ and storage capacity $(\Phi \mathrm{h})$ are functions of permeability and porosity values considering their sampling depth (equations 1 and 2 ). The values of cumulative flow and storage capacities can be determined using equations ( 3 and 4 ):

$$
\begin{aligned}
& \mathrm{Kh}=\mathrm{K}_{1}\left(\mathrm{~h}_{1}-\mathrm{h}_{0}\right), \mathrm{K}_{2}\left(\mathrm{~h}_{2}-\mathrm{h}_{1}\right), \ldots, \mathrm{K}_{\mathrm{n}}\left(\mathrm{h}_{\mathrm{n}}-\mathrm{h}_{\mathrm{n}-1}\right) \\
& \Phi \mathrm{h}=\Phi_{1}\left(\mathrm{~h}_{1}-\mathrm{h}_{0}\right), \Phi_{2}\left(\mathrm{~h}_{2}-\mathrm{h}_{1}\right), \ldots, \Phi_{\mathrm{n}}\left(\mathrm{h}_{\mathrm{n}}-\mathrm{h}_{\mathrm{n}-1}\right) \\
& \mathrm{Kh}_{\text {cum }}=\mathrm{K}_{1}\left(\mathrm{~h}_{1}-\mathrm{h}_{0}\right) / \mathrm{Kh}_{\text {Total }}+\mathrm{K}_{2}\left(\mathrm{~h}_{2}-\mathrm{h}_{1}\right) / \mathrm{Kh}_{\text {Total }}+\ldots .+\mathrm{K}_{\mathrm{n}}\left(\mathrm{h}_{\mathrm{n}}-\right.
\end{aligned}
$$

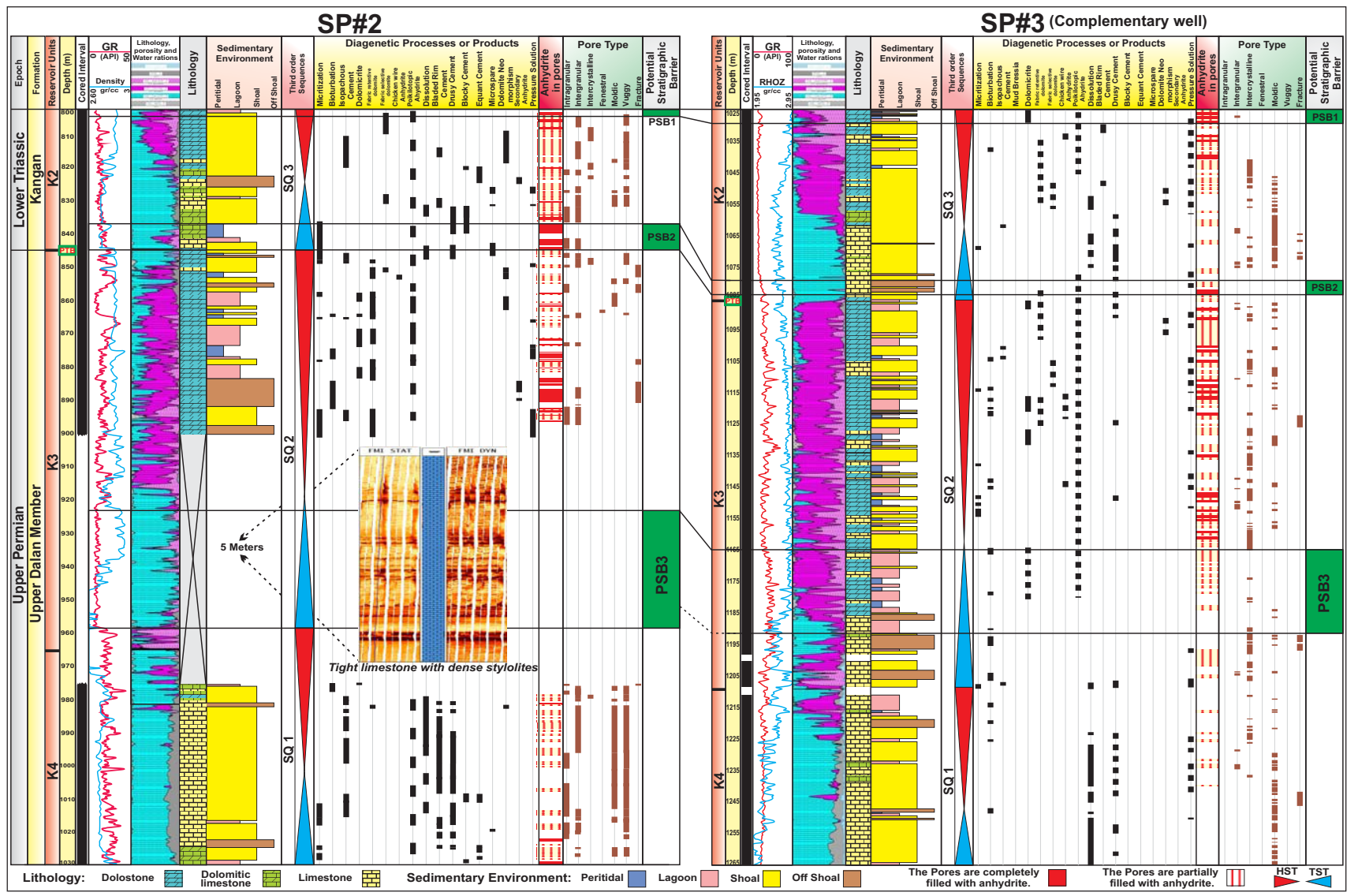

FIGURE 5 $\quad$ Detecting Potential Stratigraphic Barriers (PSB) based on petrographic analysis in SP\#2 and SP\#3 wells (see text for details). 
$\left.\mathrm{h}_{\mathrm{n}-1}\right) / \mathrm{Kh}_{\text {Total }}$

$$
\Phi \mathrm{h}_{\text {cum }}=\Phi_{1}\left(\mathrm{~h}_{1}-\mathrm{h}_{0}\right) / \Phi \mathrm{h}_{\text {total }}+\Phi_{2}\left(\mathrm{~h}_{2}-\mathrm{h}_{1}\right) / \Phi \mathrm{h}_{\text {total }}+\ldots .+\Phi_{\mathrm{n}}\left(\mathrm{h}_{\mathrm{n}}-\mathrm{h}_{\mathrm{n}-1}\right) /
$$

$\Phi h_{\text {total }}$

Where $\mathrm{K}$ is permeability $(\mathrm{mD}), \mathrm{h}$ is sample depth (m) and $\Phi$ is fractional porosity.

The break or inflection points reveal the number of preliminary flow units in the SMLP (Fig. 7A). Thus, the upper Dalan and lower Kangan reservoir intervals were subdivided into ten flow units (FUs; Fig. 7A). The slope of each segment is indicative of the flow performance in the reservoir (Gunter et al., 1997). Steep slopes are indicative of permeable high performance flow units (Gomes et al., 2008) and gentle slopes or horizontal segments are representative of low permeability units or flow barriers. These ten flow units can be observed in six studied wells (Fig. 7B).

Two additional parameters, the reservoir process speed and $R_{35}$ also assisted with the definition of the ten flow units. The reservoir process speed (Chopra et al., 1987) or delivery speed (Aguilera, $2004)$ is the permeability to porosity ratio $(K / \Phi)$. This method is one of the best approaches for determining the preliminary flow units (high permeable zones, tight zones and seals) in the porous media using conventional core analysis data (Gunter et al., 1997; Aguilera, 2004; Gomes et al., 2008; Rahimpour-Bonab et al., 2012). $\mathrm{R}_{35}$, or pore throat radius at $35 \% \mathrm{Hg}$ saturation, is obtained from core and logs using the Winland equation (Eq. 5; Kolodzie, 1980) or directly from capillary pressure data. The $R_{35}$ value provides the basis for a common zonation that can be used by both geologists and reservoir engineers, and provides an alternative approach to the definition of flow units in the absence of special core analysis data (Martin et al., 1997):

$\log \mathrm{R}_{35}=0.732+0.588 * \log (\mathrm{K})-0.864 * \log (\mathrm{Phi})(5)$

Where,

$\mathrm{R}_{35}$ : is a port radius at $35 \% \mathrm{Hg}$ saturation $(\mu \mathrm{m}), \mathrm{K}$ : is permeability $(\mathrm{mD})$, Phi: is fractional porosity
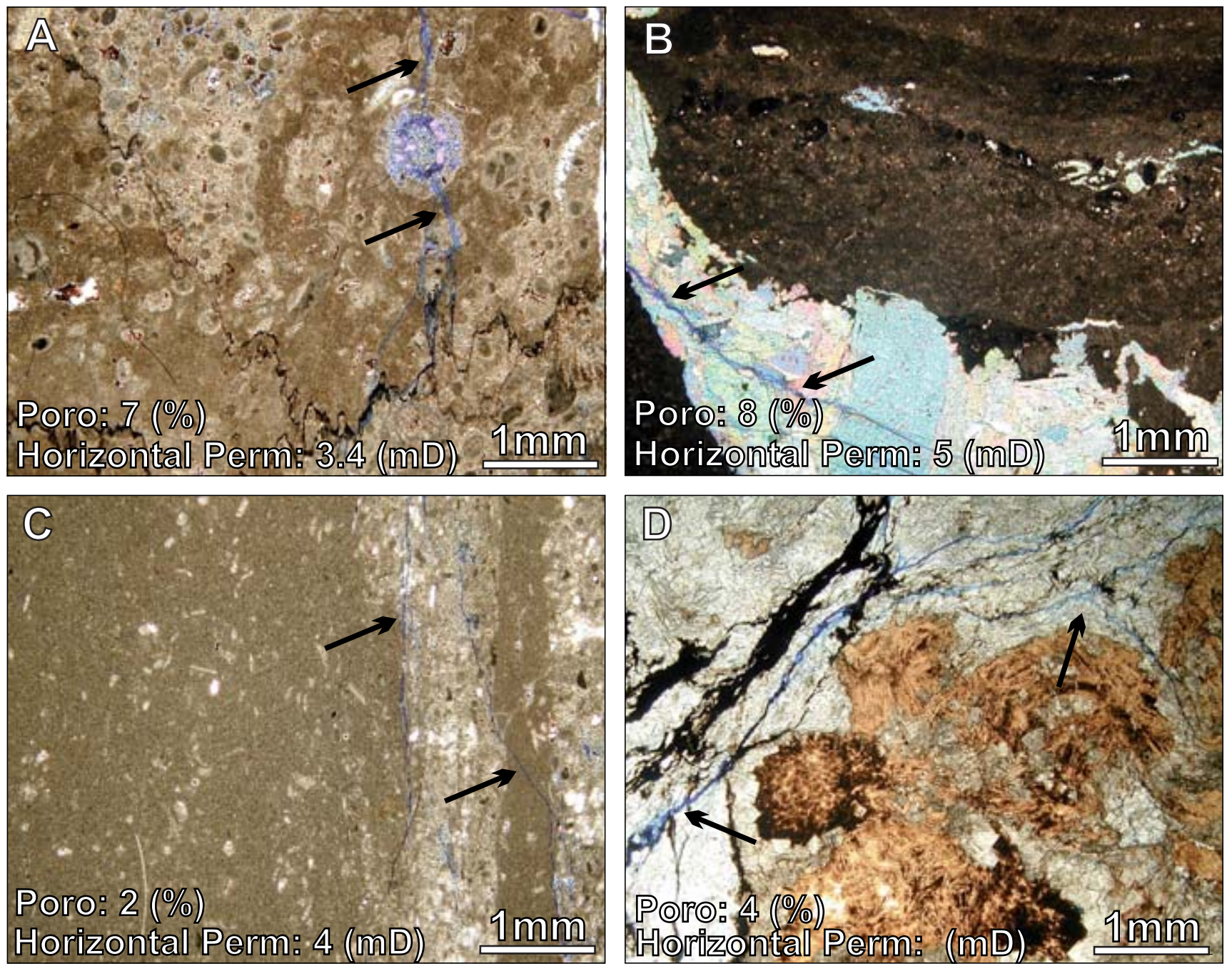

FIGURE 6 $\quad$ The mud dominated and compacted unit with poor reservoir quality based on depositional characteristics in the middle part of K3 (SP\#2). It could not be a barrier unit due to fracturing (samples are from 884-892m interval). 

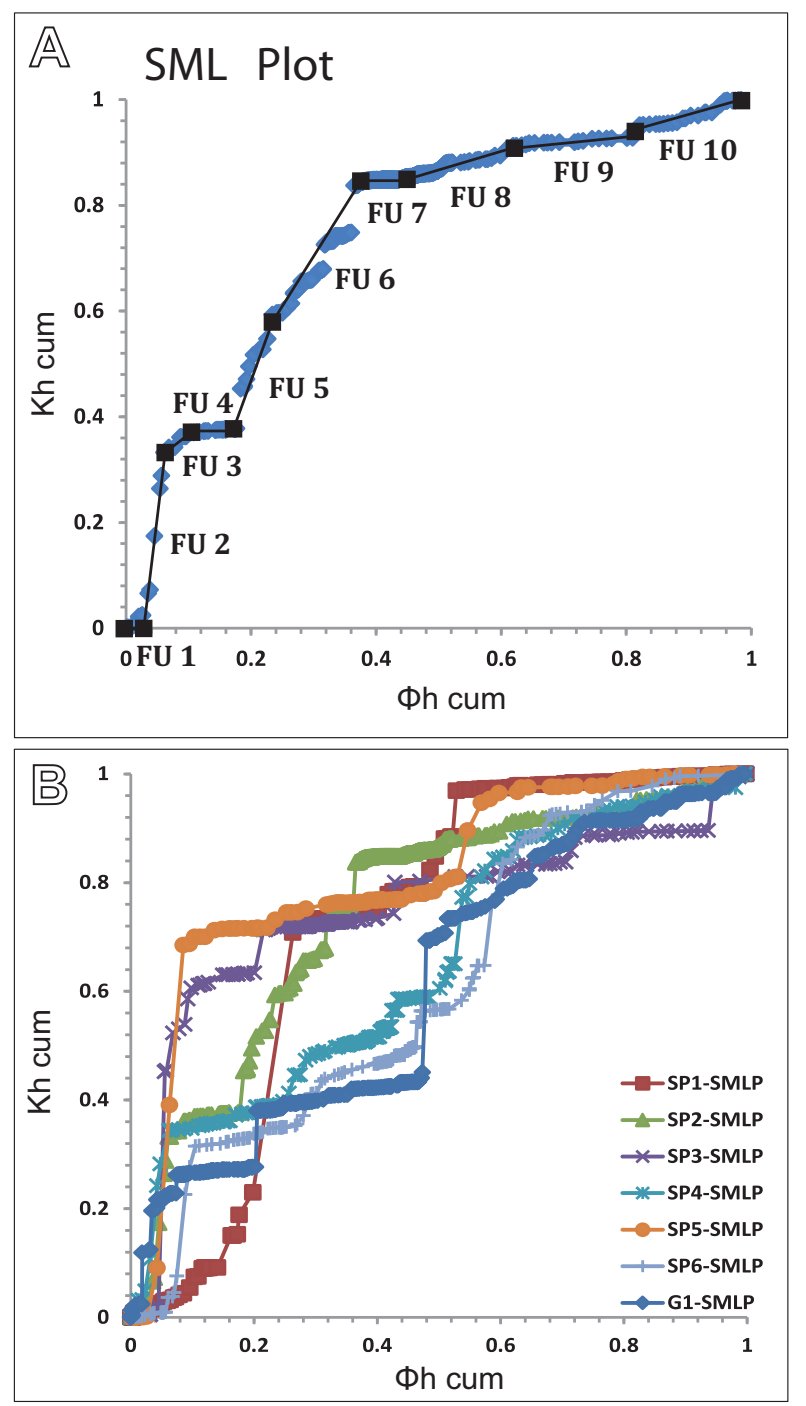

FIGURE 7 A) Stratigraphic Modified Lorenz Plot (SML plot) composed of cumulative storage capacity $\left(\Phi h_{\text {cum }}\right)$ vs. cumulative flow capacity $\left(\mathrm{Kh}_{\text {cum }}\right)$. Break or inflection points caused to ten preliminary flow units; B) Constructed SML plots for seven studied wells which all could be divided into ten segments or flow units.

After determining the number of flow units using the SMLP (Fig. 8), the stratigraphic flow profile was constructed in which sequence stratigraphic position, lithologic and depositional facies properties, poroperm values, pore throat characteristics $\left(\mathrm{R}_{35}\right.$ and $\mathrm{K} / \Phi)$ and flow/storage capacities (Kh\% and $\Phi \mathrm{h} \%)$ are compared (Fig. 8). In this study, four main types of flow unit have been defined:

i) Normal flow units: with approximately high or equal values of the storage and flow capacities (FU3, FU6 and FU8 in Figs. $7 ; 8)$.

ii) Super permeable units: with high flow and low storage capacities and steep slopes in the SML plot (FU2 and FU5 in Figs. 7; 8).

iii) Baffle units: low flow and high storage capacities (FU9 and FU10 in Figs. 7; 8) are the main characteristics of these units. These are mainly units with reduced pore and port sizes due to meteoric cementation (isolated molds and separate vugs), or several irregularly distributed mud-dominated off-shoal intercalations within the porous and permeable shoal bodies.

iv) Barrier units: impermeable units with very low flow and storage capacities. For such units, the slope of the SMLP is very low (FU1, FU4 and FU7 in Figs. 7; 8).

Based on the SMLP and the stratigraphic flow profile, defined flow units in SP\#2 well are in a descending order of reservoir quality as follows: FU2, FU5, FU6, FU3, FU8, FU10, FU9, FU1, FU4 and finally FU7 (Fig. 7; 8).

The main sedimentological and petrophysical characteristics of the defined flow units in the seven wells of the studied fields are summarized in Table II. Three main barrier units were detected in all studied wells. Additionally, the lithological, sedimentological and petrophysical characteristics of individual flow units have good and reliable similarities in the wells (Table II).

Three-D SEM images (Fig. 9) can be used to characterize pore networks (Pittman and Thomas, 1979). Moreover, capillary pressure measurements provide valuable information for reservoir rock evaluation, estimating the fluids contact depth in the reservoir, seal properties, and pores system characteristics such as pore size distribution and pore-throat size sorting (Wardlaw and Taylor, 1976; Kolodzie,1980; Swanson, 1981; Katz and Thompson, 1986, 1987; Wardlaw et al., 1988; Pittman, 1992; Tiab and Donaldson, 2004; see Figure 9). An integration of these methods is a powerful approach in pores system characterization and reservoir quality studies which can provide an additional support to the flow unit definition approach previously defined.

Each flow/barrier unit is depicted in Figure 9 with i) a representative reservoir rock sample; ii) corresponding pore throat size distribution curve and iii) an SEM photomicrograph. The pore system characteristics and the variety of pore types are reflected in the pore throat size distribution curves. The ten flow units identified in the SP\#2 well are characterized in the following scheme:

FU1: This barrier unit is composed mainly of anhydritic dolostone related to shoal and lagoonal facies. Pores are mainly occluded by anhydritic or dolomitic cements (usually in the shoal facies). The poroperm values $(\Phi<2 \%$ and $K<0.1 \mathrm{mD}), \mathrm{R}_{35}$ and flow/storage capacities are very low and indicate a tight rock unit (Fig. 8, FU1; Table II). The reservoir/flow quality is the result of interaction between depositional rock fabric and diagenetic overprints in this unit. Stratigraphically, this unit is located in the late HST of sequence SQ3. The reservoir quality and pores system characteristics in the basal part of this unit are weaker than in the underlying flow unit FU2 (Fig. 9, FU1 and FU2). In this basal part, SEM photomicrograph, illustrate rhombic dolomite crystals and small interparticle pore spaces in a dolomitic shoal 


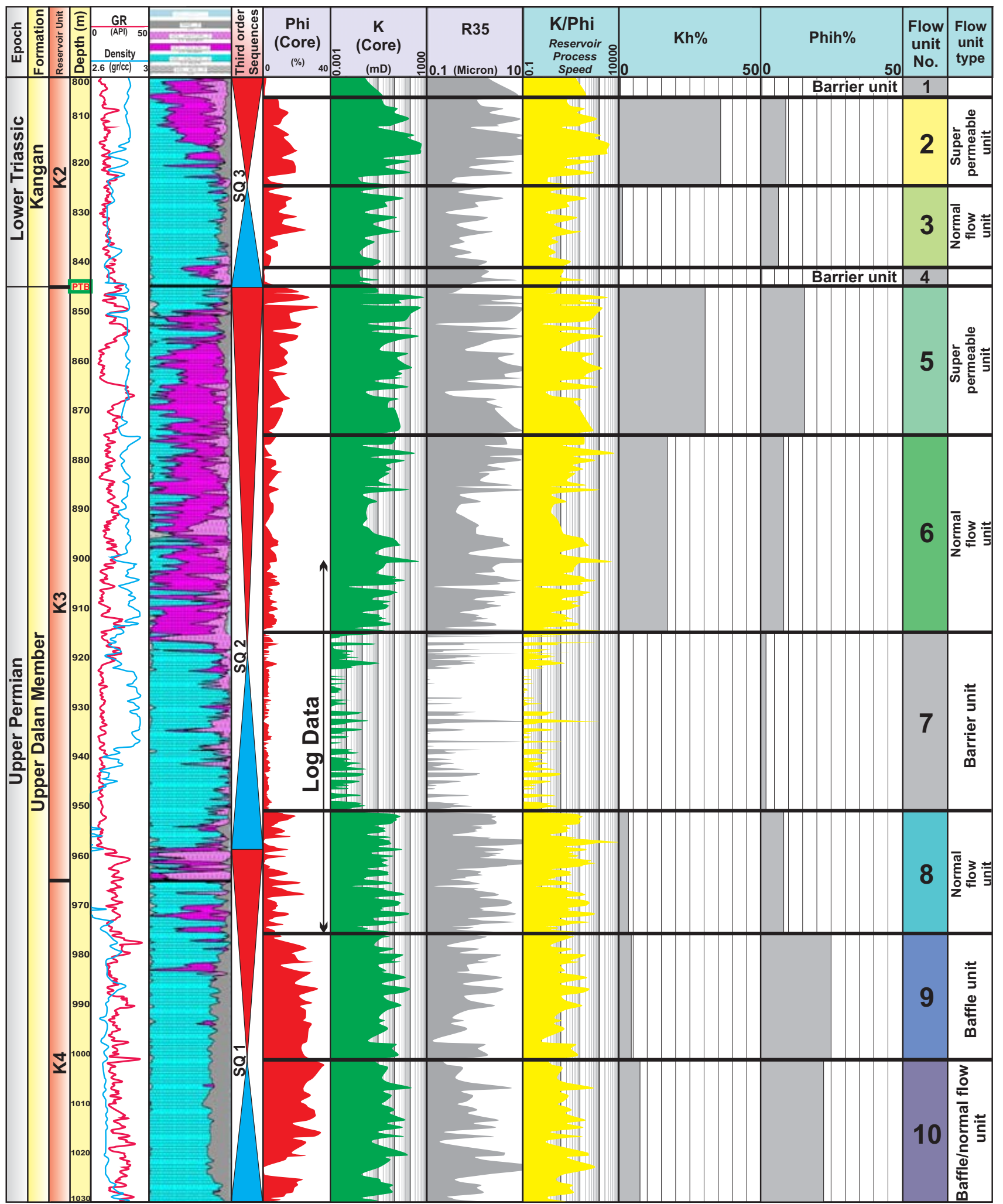

FIGURE 8 Stratigraphic Flow Profile (SFP) and final flow units in well SP\#2. FU1, FU4 and FU7 have very low flow and storage capacities, therefore they are considered as barrier units. The FU2 and FU5 units have high flow capacity with low storage capacity so they are super permeable units. The FU9 has high storage capacity but low flow capacity and is a baffle unit. 
facies (Fig. 9, FU1). The port size distribution curve is unimodal and leptokurtic and the most abundant pore throat radius is around 10 microns; but the tail of distribution, provide evidence of heterogeneity in the pore network and fluid flow. In spite of the relatively high (horizontal) permeability of this sample $(29 \mathrm{mD})$, its vertical permeability is probably low. This is because the wellconnected pore network is local and not continuous (Fig. 9: FU1, central part of thin section image has good porous network, while borders are tight).

FU2: The permeability of this unit is very high (max: $500 \mathrm{mD}$ ). Limestone and dolostone (resulting from seepagereflux) are the main lithologies and shoal facies are dominant. Patchy and poikilotopic types of anhydrite cement are present, but the poroperm values have not been considerably affected (Lucia, 1992; Rahimpour-Bonab et al., 2010). According to the poroperm values, $R_{35}$ and flow capacity, the reservoir quality of this unit is the highest of any defined flow unit (Fig. 8, FU2; Table II). As illustrated in the SEM photos, the main pore type is intercrystalline (Fig. 9, FU2). The port size distribution curve is representative of a poorly sorted pore throat system resulting from the irregular distribution of interparticle cements and different sizes of dolomite crystals.

FU3: this flow unit consists of shoal facies including limestone with different types of calcite cements including bladed, blocky and equant types that formed in meteoric and shallow burial environments and pore filling anhydrite. Interparticle, moldic and vuggy pore spaces are the most important pore types. Dissolution which is responsible for the creation of moldic and vuggy pores is another notable diagenetic feature in FU3. The poroperm and $R_{35}$ values are representative of fair to low flow capacity which is related to the weak connectivity of ports between separated molds and vugs owing to various cement types (Fig. 8 and 9 FU3 and Table II). The SEM analysis shows that the main mineral is calcite with very rare rhombic dolomite crystals (Fig. 9, FU3). The port size frequency is relatively unimodal but weakly distributed in the sample (Fig. 9, FU3). The pore system heterogeneity exhibits fluids movement (Fig. 9, FU3). The presence of anhydrite and calcite cements interrupts the connectivity between larger pores and significantly decreases the permeability $(<10 \mathrm{mD})$ of the reservoir rock. The differences between the solubility of minerals and the presence of large amounts of cements in the pore system are the main elements responsible for this heterogeneity which is much more common in limestone samples than dolostones.

FU4: This barrier unit is mainly composed of tight muddominated limestone related to peritidal and lagoonal facies. There is some evidence of calcite cementation in meteoric and shallow burial environments (shoal facies) with some microspars resulting from micrite recrystallization (Fig. 9, FU4). Anhydrite cement occludes pore spaces and chemical compaction produces macro/microstylolites, which result in further reducing reservoir quality (Fig. 9, FU4). Very low poroperm values $(\Phi<1 \%$ and $\mathrm{K}<0.07 \mathrm{mD})$ and low flow $/$ storage capacity $(\mathrm{Kh} \%=0.01$ and
$\Phi \mathrm{h} \%=0.5$ ) of the unit is indicative of its tight nature (Fig. 8; Table II). The SEM photomicrograph shows very dense limestone (Fig. 9, FU4). This unit is representative of early TST deposits in the sequence stratigraphic framework (Fig. 9, FU4).

FU5: This is a dolomitic/limy super permeable unit which consists of shoal, lagoonal and peritidal facies below the PTB. The main effect of the PTB is to decrease the poroperm values as a result of meteoric and pore-filling anhydrite cementation just below the PTB (Fig. 8 FU5). Patchy and poikilotopic anhydrite cements exist with minor effect on reservoir quality (Fig. 9 FU5). The poroperm values $(\Phi$ mean $=13 \%$ and Kmean $=70 \mathrm{mD})$ and flow capacity $(\mathrm{Kh} \%=30)$ are high (Fig. 8 and Table II) as a result of the uniform intercrystalline/intergrain pore networks. Because of the presence of such pore spaces, the port size distribution curve is bimodal and leptokurtic (Fig. 9 FU5).

FU6: This unit mainly consists of off-shoal, shoal and lagoonal facies including dolostone with patchy and poikilotopic types anhydrite cements. Dolomitization is the main diagenetic feature which is responsible for the high flow capacity (Fig. 8, FU6; Table II), particularly in mud-dominated (lagoonal and offshoal) facies. Grain dominated fabrics with intergranular pore spaces created a good network for fluid flow as illustrated in the SEM photomicrograph (Fig. 9, FU6). In the middle parts of this unit, anhydrite cementation decreases the reservoir quality of the shoal facies (Fig. 8, FU6, 890-895m). The port size distribution curve is similar to that of the basal FU1 (Fig. 9), and according to SEM studies, both pore types and permeability values are similar.

FU7: According to the well logs analyses and equivalent units in neighboring wells, the main lithology of this unit is limestone with anhydrite cements. Based on the density and image (FMI) $\operatorname{logs}$, this unit is a tight and compacted interval which is mainly composed of limestone lithology with high concentrations of horizontal macro and microstylolites. Mud-dominated lagoonal and peritidal facies with frequent horizontal stylolites are the main characteristics of this unit (Fig. 5, 1165-1190m). The low poroperm values $(\Phi$ mean $=3 \%$ and $\mathrm{Kmean}=0.3 \mathrm{mD})$ and flow capacity $(\mathrm{Kh} \%=0.1$; Fig. 8 ; Table II $)$ are related to the tight nature of the unit. The thickness, lateral continuity and sedimentological and petrophysical properties improve the sealing potential of the unit as a very effective flow barrier and even a potential cap rock for the underlying K4 reservoir unit (Fig. 8, FU7). This unit is identified as a TST deposit in the SP\#3 well (Fig. 5).

FU8: The main lithology in this unit is limestone but anhydrite cements (or intercalations) and dolomites are present particularly in the middle parts of the unit (Fig. 8, FU8). FU8 is made up of shoal and off-shoal facies (Fig. 5). The poroperm values $(\Phi$ mean $=8.4 \%$ and $\mathrm{Kmean}=7.6 \mathrm{mD})$ and the flow/storage capacities $(\mathrm{Kh} \%=3$ and $\Phi \mathrm{h} \%=8)$ indicate a flow unit (Fig. 8, FU8; Table II).

FU9: The lithology of this baffle unit is limestone including 


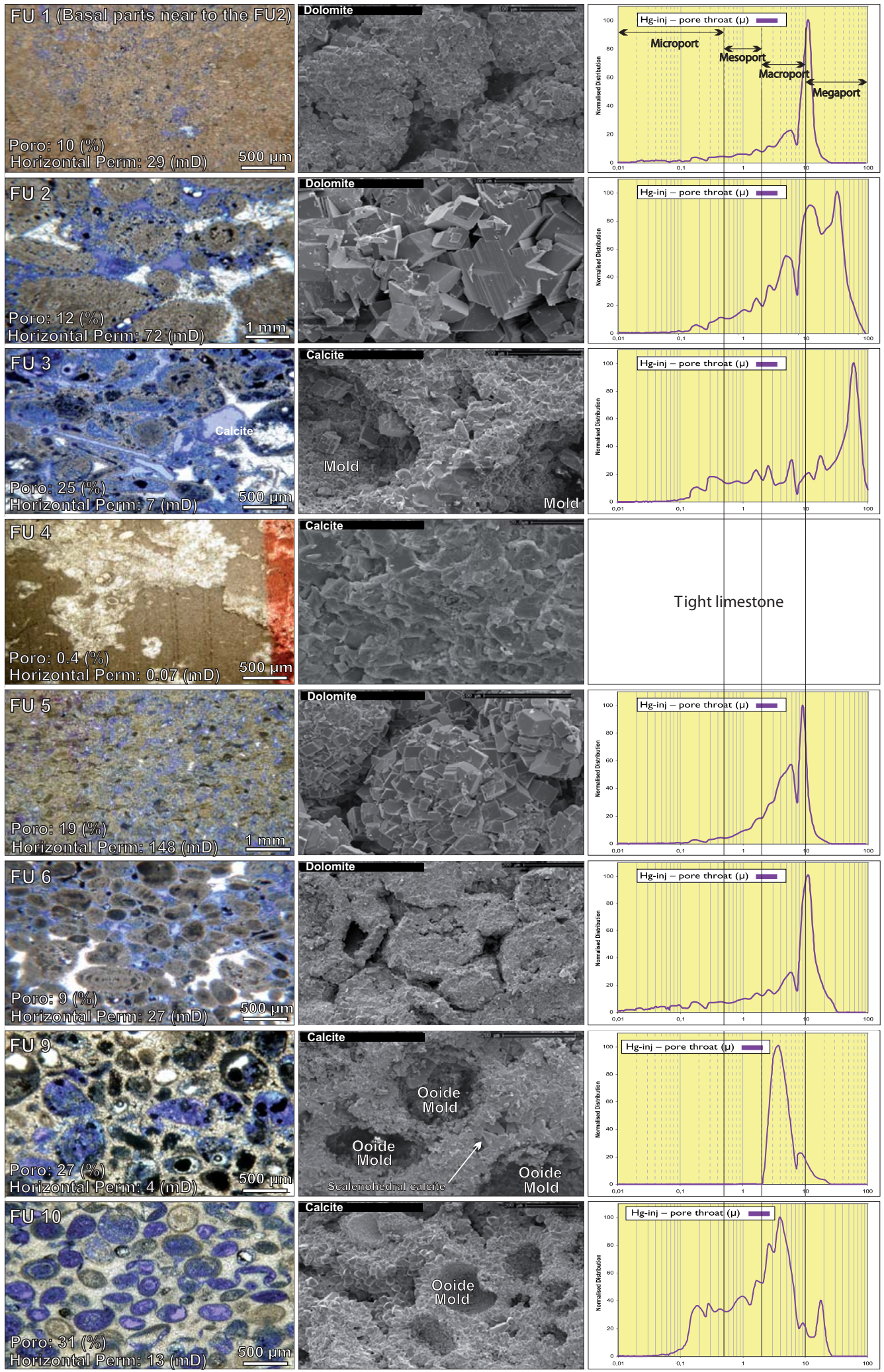

FIGURE 9 Some examples of defined flow units in well SP\#2 with a represent the SEM photograph and the port size distribution (from Hg injection). This plate indicates the different flow potential of the distinguished flow units (FU7 and FU8 are not illustrated because they are located in an un-cored interval at the middle and lower parts of the K3 unit). According to the definition of Martin et al. (1997) port sizes are grouped to Mega, Macro, Meso and Micro ranges (Location of samples: FU1, 803.90m; FU2, 812.3m; FU3, 831.2m; FU4, 841m; FU5, 851.3m; FU6, 895m; FU9, 994.7m; FU10, 1009.6m). 
grain-dominated shoal facies. The main pore types are moldic, vuggy and intergranular which cause the porosity and the storage capacity to be high (Figs. 8; 5; Table II). There are various types of cements such as marine isopachous, meteoric and pore filling anhydrite (Fig. 9, FU9), which have played an important role in decreasing the reservoir quality. According to the SEM studies (Fig. 9, FU9), there are pore spaces (molds) which are distributed separately in a calcite matrix. In spite of different pore types and cements (scalenohedral calcite crystals in the intergranular pore spaces), the port size distribution is uniform (Fig. 9, FU9).

FU10: This unit is similar to the FU9 but with better flow capacity or permeability (Figs. 8, FU9; 10; Table II). As indicated in the SEM photomicrographs (Fig. 9, FU10), calcite cement crystals precipitated in marine or meteoric environments are responsible for decreasing pore/port sizes and for generating a semi baffling flow behavior. According to Figure 9, pores system characteristics and port diameters have been decreased due to extensive calcite cementation. As a result of connected ooid molds and dissolved spastolites, the permeability values are better than the FU9.

To summarize, the flow units are defined based on their reservoir quality. The poroperm values in the defined flow units

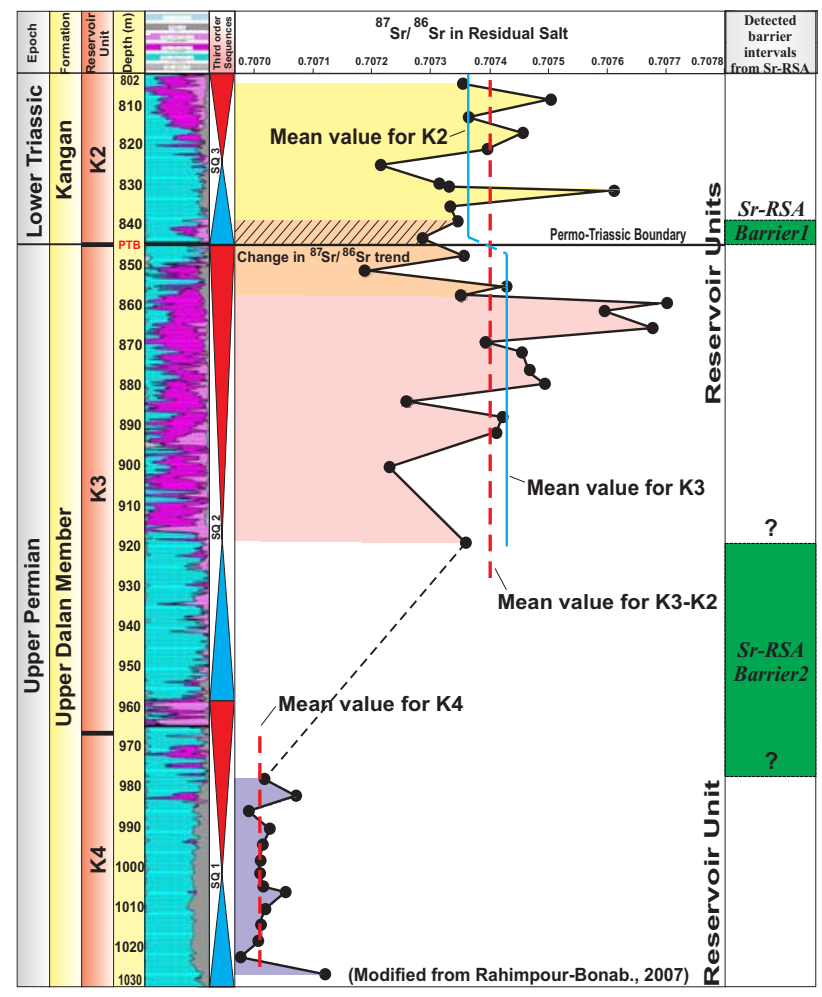

FIGURE 10 Residual salts ${ }^{87} \mathrm{Sr} /{ }^{86} \mathrm{Sr}$ ratios show two major trends in the K2-K3 and K4 reservoir units (red dashed lines) of well SP\#2 with two subordinate trends in the K2-K3 reservoir units (blue lines). Two barrier units in the lower K3 and basal K2 reservoir units were detected using this approach (Sr-RSA barrier 1 and 2). are compatible with the pore system structure and rock properties at microscopic scale. The distribution of the flow units, high permeability zones, barriers and baffles were determined using core and log data from seven wells in the studied fields (South Pars and Golshan).

\section{Strontium residual salt analysis}

Strontium Residual Salt Analysis (Sr-RSA) is one of the most commonly applied geochemical methods used to detect reservoir compartmentalization (Smalley et al., 1995; Rahimpour-Bonab, 2007). This method is based on identifying variations in the $87 \mathrm{Sr} / 86 \mathrm{Sr}$ ratios of formation water composition. The presence of flow barriers in the reservoir body or aquifer rocks prevents the $87 \mathrm{Sr} / 86 \mathrm{Sr}$ ratios from being homogeneously distributed in the precipitated salts derived from the reservoir fluids. Consequently, inconsistency in $87 \mathrm{Sr} / 86 \mathrm{Sr} \operatorname{logs}$ (Smalley et al., 1995) allows flow barriers and associated reservoir compartmentalization to be distinguished (Fig. 10). $87 \mathrm{Sr} / 86 \mathrm{Sr}$ ratios of the core residual salts of well SP\#2 (with mean uncertainty about $\pm 0.000018(2 \sigma)$; Rahimpour-Bonab, 2007) indicate that there are two barrier units which disconnect the reservoir fluids between each of the K2, $\mathrm{K} 3$ and $\mathrm{K} 4$ units as identified by differences in the trend of the $87 \mathrm{Sr} / 86 \mathrm{Sr}$ ratio. The main reason for the sharp difference in $87 \mathrm{Sr} / 86 \mathrm{Sr}$ ratios across the K3-K4 boundary (red dashed mean lines in Fig. 10) is the higher dolomite and anhydrite content (higher $87 \mathrm{Sr} / 86 \mathrm{Sr}$ ratio) in $\mathrm{K} 3$ unit in comparison to the $\mathrm{K} 4$ which is limestone. There are two subordinate trends (blue lines in Fig. 10 ) in the mean $87 \mathrm{Sr} / 86 \mathrm{Sr}$ line of the $\mathrm{K} 2-\mathrm{K} 3$ interval (red dashed line) indicating a shift toward lower values from $\mathrm{K} 3$ to $\mathrm{K} 2$ which is correlatable with a dense unit (barrier) at the lowermost K2.

These deflections in $87 \mathrm{Sr} / 86 \mathrm{Sr}$ ratio identify two impermeable units (Sr-RSA barriers 1 and 2 in Fig. 10) which hindered the movement of reservoir fluids between the K2, K3 and K4 reservoir units. One of these deflections occurs within the interval 920-980m (Fig. 10) (Sr-RSA Barrier 2) thick that separates the $\mathrm{K} 4$ unit from overlying unit K3. The second deflection in the 87Sr/86Sr occurs near the K2-K3 boundary (PTB; Fig. 10), which is indicative of another tight unit (Sr-RSA Barrier 1). To summarize, in the SP\#2 well, there are two major compartments (K2/K3 and K4). One of these compartments can be further subdivided into two minor compartments (K2 and K3; Fig. 10).

\section{DISCUSSION}

In this study, the Intra Reservoir Barriers (IRBs) and reservoir compartmentalization were evaluated in the South Pars gas field using various types of data set including the petrographical, petrophysical and geochemical properties. IRBs have been identified as a result of data integration and sequence stratigraphic correlation at the field scale. There is a good agreement between the results of the petrographical (PSBs 1, 2 and 3; Fig. 5), petrophysical (FUs 1, 4 and 7; Fig. 8) and geochemical (Sr-RSA 
barriers 1 and 2; Fig. 10) studies (Fig. 11). The defined reservoir compartmentalization based on flow unit and IRB identification was detected in the other wells and the neighboring Golshan Field using the SMLP method (Fig. 12).

Depositional facies properties such as mud-dominated fabrics, peritidal (anhydrite bearing), lagoonal and off-shoal facies and diagenetic processes including anhydrite and calcite cementation, micrite recrystallization and stylolitization are the main factors that produce IRBs throughout unit $\mathrm{K} 2$, in the lower part of unit $\mathrm{K} 1$ and in the lower part of unit K3 in the studied wells (Fig. 13).

IRB1 is a late HST dolomitic unit with layers of anhydritic cements which is composed of peritidal and shoal facies. Early depositional features including mud-dominated fabrics and syndepositional anhydrite precipitation together with diagenetic overprints such as brecciation, pore-filling anhydrite cements and chemical/mechanical compaction created this tight horizon (Fig, $13 \mathrm{~A}, \mathrm{~B}, \mathrm{C})$. Interaction of depositional rock fabrics and diagenetic overprints are reflected in the very low poroperm (mainly $\Phi<2 \%$ and $\mathrm{K}<0.1 \mathrm{mD}$ ) and weak flow properties such as $\mathrm{R}_{35}$ (mainly $<1 \mu \mathrm{m}$ ) and flow/storage capacities (mainly $\mathrm{Kh} \%<1$ and $\Phi \mathrm{h} \%<1$ ). Because there is no geochemical data for K1 unit, IRB1 is only proved by petrographical and petrophysical approaches.

IRB2 is an early TST limestone unit made up of peritidal (thrombolitic) or off-shoal facies. The mud-dominated fabrics and meteoric calcite cements, pore-filling anhydrite, micrite recrystallization and chemical/mechanical compaction are the main depositional and diagenetic features (Fig. 13 D, E, F) that led to the weak reservoir quality. This is reflected in very low poroperm and $\mathrm{R}_{35}$ values (mainly $\Phi<2 \%, \mathrm{~K}<0.1 \mathrm{mD}$ and $\mathrm{R} 35<1 \mu \mathrm{m}$ ) and low flow/storage capacities (mainly $\mathrm{Kh} \%<0.5$ and $\Phi \mathrm{h} \%<1$ ). The barrier nature of this IRB is substantiated by $87 \mathrm{Sr} / 86 \mathrm{Sr}$ ratios that demonstrate a shift toward lower values from $\mathrm{K} 3$ to $\mathrm{K} 2$.

IRB3 is a TST rock unit which is mainly composed of lagoonal, peritidal and shoal/off-shoal facies in the studied wells. The lithology variations include anhydritic limestone (in SP\#1,

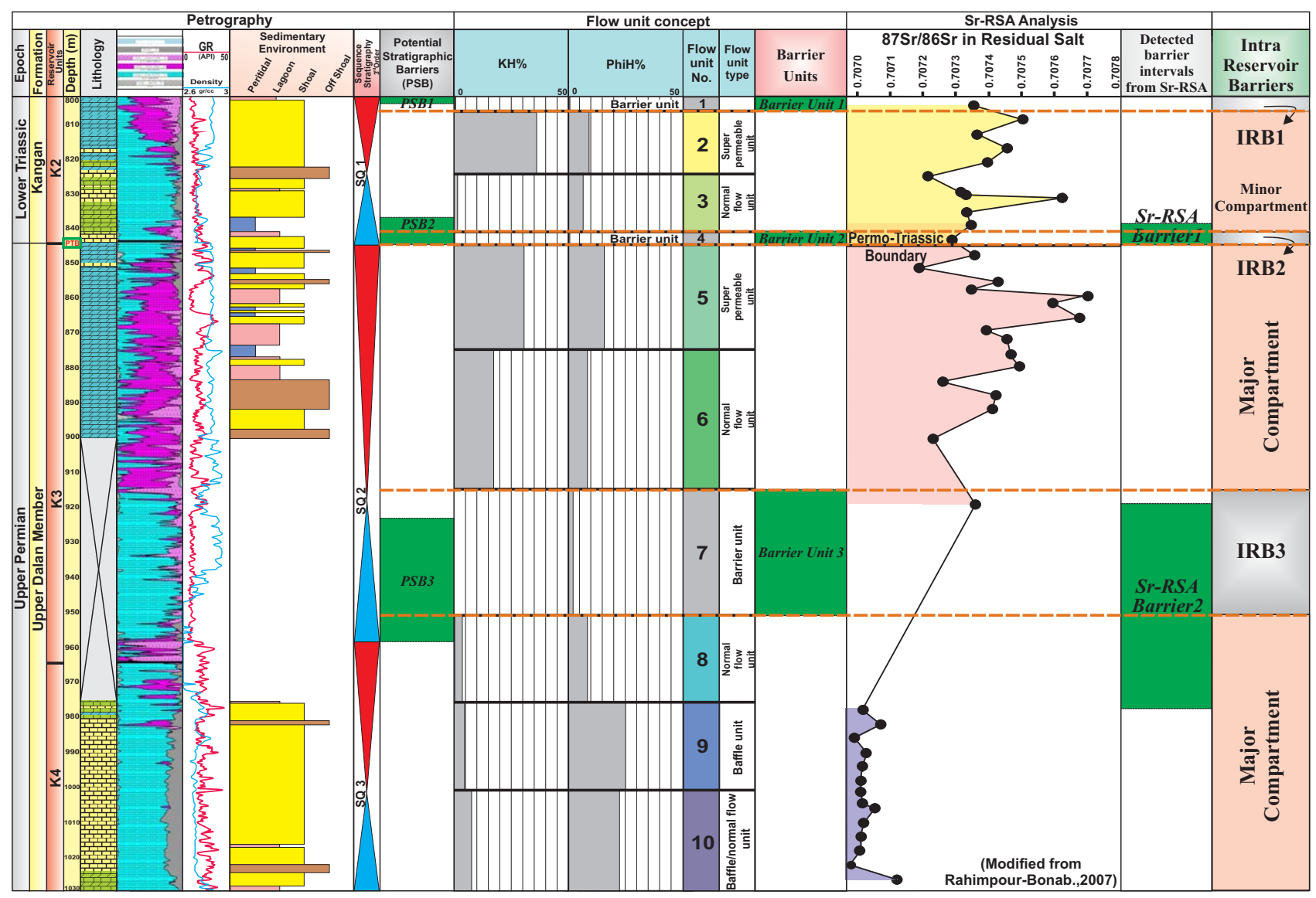

FIGURE 11 The correlation of recognized IRB units resulted from three approaches including petrography, petrophysic (SMLP) and geochemistry (Sr-RSA). Two intra reservoir barriers (IRB2 and IRB3) were confirmed by all three approaches and one IRB (IRB1) was identified by petrographical and petrophysical approaches (since Sr-RSA data was not available above the K2 unit). 
SP\#2 and G1 wells) to anhydritic dolostone (in SP\#3 to SP\#6 wells). The depositional and early diagenetic features including mud-dominated fabrics, anhydrite intercalations, nodules and cements along with the later diagenetic features such as intense chemical compaction (stylolitization) and pore-filling anhydrite cements helped to form a thick and impermeable barrier unit with very weak reservoir quality (mainly $\Phi<2 \%, \mathrm{~K}<0.1 \mathrm{mD}, \mathrm{Kh} \%<1$, $\Phi \mathrm{h} \%<1$ and $\mathrm{R}_{35}<1 \mu \mathrm{m}$; Fig. $\left.13 \mathrm{G}, \mathrm{H}, \mathrm{I}\right)$. A very sharp change in $87 \mathrm{Sr} / 86 \mathrm{Sr}$ ratios across the $\mathrm{K} 3-\mathrm{K} 4$ boundary confirms the occurrence of this IRB.

The three identified IRBs in the upper part of K2 (IRB1), at the base of K2 (IRB2), and in the lower part of K3 (IRB3) units are closely comparable with the D1, D2 and D3 dense units described in the upper Khuff Fm. of the offshore United Arab Emirates (Alsharhan, 2006; Fig. 1 A, A'; Fig. 12). The facies characteristics in the South Pars Gas Field are similar to the upper Khuff Fm., but the formation thickness at the South Pars Field is less due to its location on a structural high (Q-SF Arch). Reservoir barriers are regionally developed from the western Q-SF arch to the south-east of the Persian Gulf and offshore United Arab Emirates (UAE) (A$\mathrm{A}^{\prime}$ transection in Fig. 1A) indicating a great lateral extension and layer-cake geometry of the reservoir body based on correlation within a sequence stratigraphic framework (Fig. 12). This is a reflection of regional scale extension of tectono-eustatic sea level fluctuations and a gradual/homogenous depositional system in a passive continental margin setting (Pillevuit, 1993; Edgell, 1996; Sharland et al., 2001; Ziegler, 2001; Alsharhan and Nairn, 2003, Insalaco et al., 2006). This geologically based reservoir layering will form the basis for ongoing dynamic reservoir modeling.

\section{CONCLUSION}

Intra Reservoir Barriers (IRBs) and reservoir compartmentalization in the prolific Permo-Triassic carbonate successions of the South Pars Gas Field have been identified by integrating different methods such as petrography, petrophysics (SMLP method) and geochemistry (Sr-RSA). Potential stratigraphic barriers (PSBs) were determined based on petrographic parameters such as mud-dominated sedimentary fabrics, impermeable and dense lithologies (anhydrite), facies types and pore-filling diagenetic cements. Barrier intervals are identified by applying the SMLP method. A reservoir layering has been constructed by identifying ten flow units in a sequence stratigraphic framework. The existence of impermeable intervals was revealed based on trends in the ${ }^{87} \mathrm{Sr} /{ }^{86} \mathrm{Sr}$ curve due to fluid separation within the reservoir. Finally, three IRBs and three reservoir compartments were detected by integrating the aforesaid approaches in the upper Dalan and lower Kangan formations intervals of the studied wells. These IRBs have a regional extension from the western Q-SF arch (Golshan Field), to the

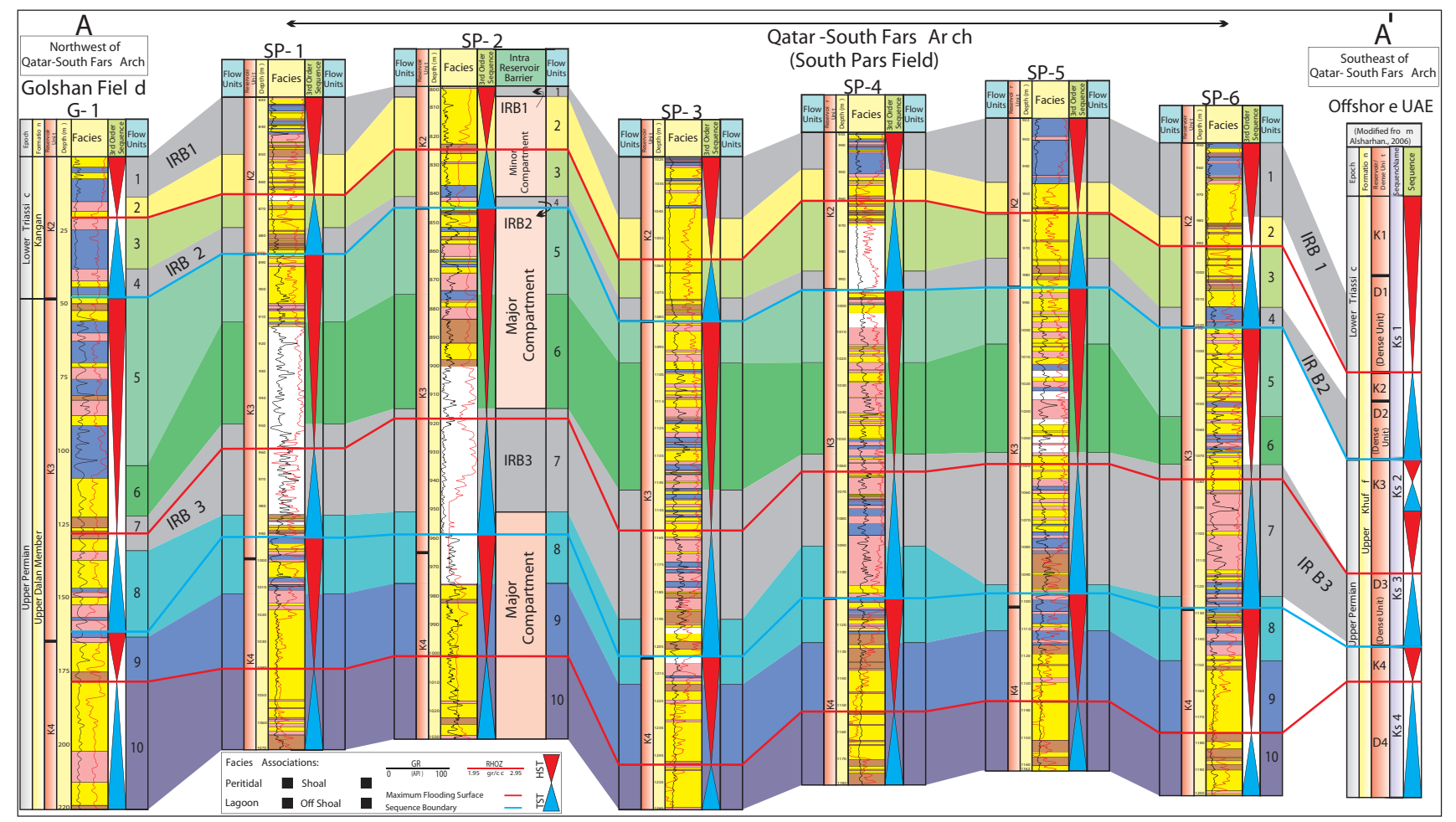

FIGURE 12 A reservoir layering for SP\#1 to SP\#6 wells constructed by correlation of defined flow units in a sequence stratigraphic framework. IRBs shown here can be correlated from the Golshan field toward the South Pars field and offshore UAE. 

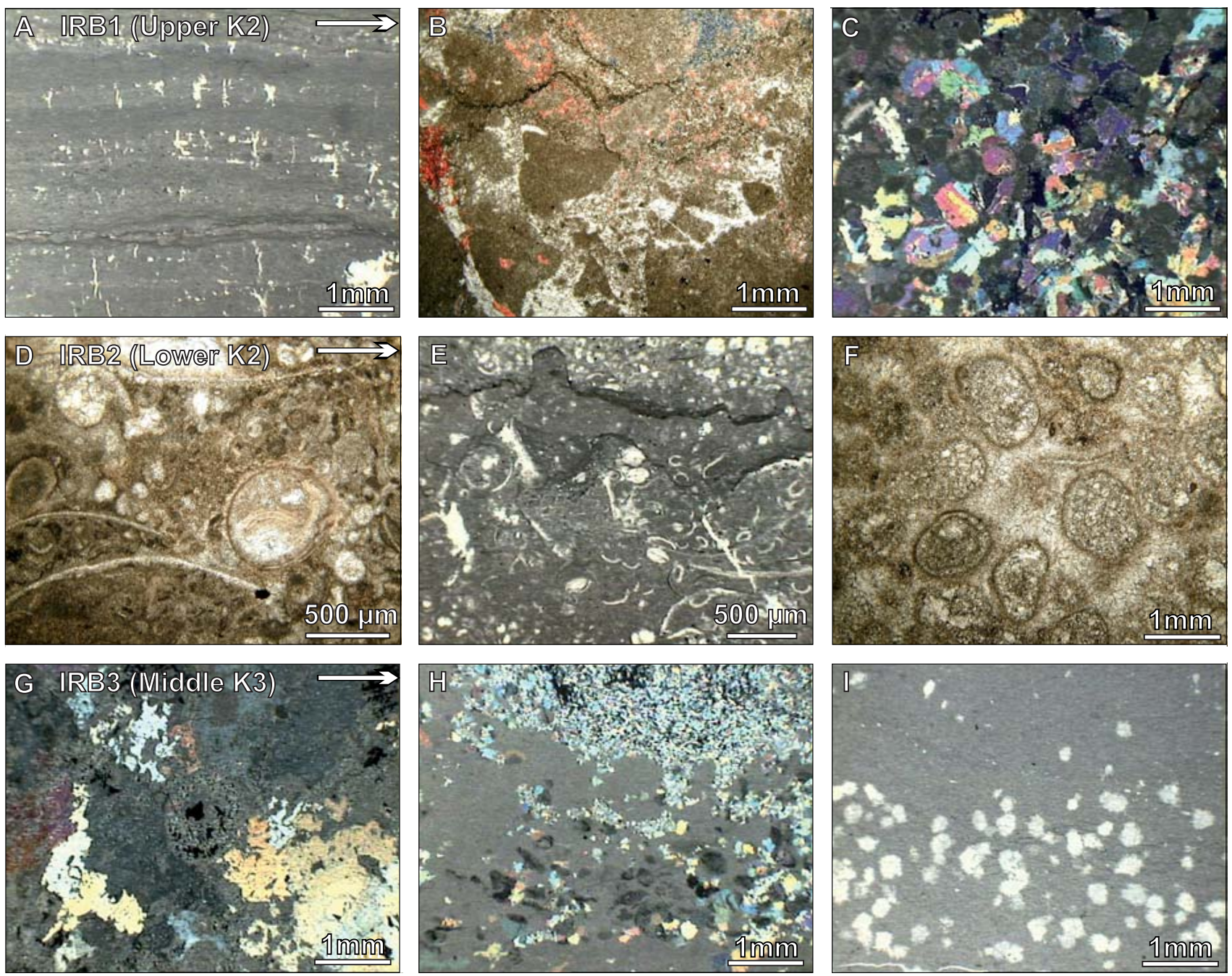

FIGURE 13 Some petrographic samples showing characteristics of the three detected IRBs. These barriers are primary low reservoir quality depositional facies affected by diagenetic processes (that have had a negative influence on reservoir quality) and commonly are related to particular stratigraphic horizons. A) Dense stromatolitic boundstone (peritidal facies) with some desiccation cracks and bird eye pore spaces filled by anhydrite (SP\#4, 946.85m; B) Dolomicritic breccia with anhydrite matrix (peritidal facies; SP\#2, 804.6m); C) Ooid grainstone plugged by anhydritic cements (shoal facies; SP\#4, 946.49m); D) Wackestone with calcite cemented pores, recrystallized patches and microstylolites (off-shoal facies; SP\#2, $840.8 \mathrm{~m}$ ); E) Wackestone with calcite/anhydrite cemented pores and highly stylolitized (off-shoal facies; SP\#4, 989.5m); F) Ooid grainstone plugged by calcite meteoric cements (shoal facies; SP\#2, 842.3m); G) Biocalstic wackestone with anhydrite cement (lagoon facies; SP\#4, 1068.8m); H) Dolomicrite with recrystallized anhydrite (peritidal facies; SP\#4, 1075.1m); I) Nodular Dolomudstone (peritidal facies; SP\#4, 1087m).

South Pars Field and probably extend to the southeastern parts of the Persian Gulf. Based on correlation with adjacent areas, the presence of IRBs and compartmentalization in the PermianTriassic reservoirs is not unexpected in this region. Use of the SMLP method is considered a useful tool for making a preliminary survey of the potential IRBs and reservoir compartmentalization.

\section{ACKNOWLEDGMENTS}

The University of Tehran provided facilities for this research for which the authors are grateful. We would like to acknowledge the management of the P.O.G.C. (Pars Oil and Gas Company of Iran) for sponsorship and data preparation. Special appreciation goes to two anonymous reviewers for their helpful comments and constructive criticism which considerably improved the quality of this manuscript.

\section{REFERENCES}

Aali, J., Rahimpour-Bonab, H., Kamali, M., 2006. Geochemistry and origin of the world's largest gas field from Persian Gulf, Iran. Journal of Petroleum Science and Engineering, 50, 161175. 
Afifi, M., 2005. Paleozoic Hydrocarbon Habitat in the Arabian Plate. Saudi Aramco. Search and Discovery Article \#10075. Adapted from American Association of Petroleum Geologists Distinguished Lecture, 2004. Houston Geological Society Bulletin, 47 (2), 15-17.

Aguilera, R., 2004. Integration of geology, petrophysics, and reservoir engineering for characterization of carbonate reservoirs through Pickett plots. American Association of Petroleum Geologists Bulletin, 88(4), 433-446.

Ahr, W.M., 2008. Geology of Carbonate Reservoirs. New York, John Wiley \& Sons Inc., 277pp.

Alavi, M., 2004. Regional stratigraphy of the Zagros fold-thrust belt of Iran and its proforeland evolution. American Journal of Science, 304, 1-20.

Alsharhan, A.S., 2006. Sedimentological character and hydrocarbon parameters of the middle Permian to Early Triassic Khuff Formation, United Arab Emirates. GeoArabia, 11(3), 121-158.

Alsharhan, A.S., Nairn, A.E.M., 1997. Sedimentary Basins and Petroleum Geology of the Middle East. Netherlands, Elsevier, first edition, 878pp.

Alsharhan, A.S., Nairn, A.E.M., 2003. Sedimentary Basins and Petroleum Geology of the Middle East. Netherlands, Elsevier, second edition, 843pp.

Andrews, L.M., Railsback, L.B., 1997. Controls on Stylolite Development: Morphologic, Lithologic, and Temporal Evidence from Bedding-Parallel and Transverse Stylolites from the U.S. Appalachian. Journal of Geology, 105, 59-73.

Bashari, A., 2005. Khuff formation Permian-Triassic carbonate in the Qatar-South Fars arch hydrocarbon province of the Persian Gulf. First Break, 23, 43-50.

Bhattacharya, S., Byrnes, A.P., Watney, W.L., Doveton, J.H., 2008. Flow unit modeling and fine-scale predicted permeability validation in Atokan sandstones: Norcan East field, Kansas. American Association of Petroleum Geologists Bulletin, 92(6), 709-732.

Chopra, A.K., Stein, M.H., Ader, J.C., 1987. Development of reservoir descriptions to aid in design of EOR projects. Ventura (California), Society of Petroleum Engineers Paper 16370, presented at the Society of Petroleum Engineers California Regional Meeting, 437-449.

Dickson, J.A.D., Saller, A.H., 1995. Identification of subaereal exposure surfaces and porosity preservation in Pennsylvanian and Lower Permian shelf limestones, eastern Central Basin Platform, Texas. In: Budd, D.A., Saller, A.H., Harris, P.M. (eds.). Unconformities and Porosity in Carbonate Strata. American Association of Petroleum Geologists, 63 (Memoir), 239-257.

Ebanks, W.J.Jr., 1987. Flow unit concept- Integrated approach to reservoir description for engineering projects. American Association of Petroleum Geologists Bulletin, 71(5), 551552.

Edgell, H.S., 1977. The Permian system as an oil and gas reservoir in Iran, Iraq and Arabia. Tehran, Proceeding Second Iranian Geological Symposium, 161-201.
Edgell, H.S., 1996. Salt Tectonic in the Persian Gulf Basin. In: Alsop, G.I., Blundell, D.J., Davison, I. (eds.). Salt Tectonics. Geological Society of London, 100 (Special Publications), 129-151.

Ehrenberg, S.N., 2006. Porosity destruction in carbonate platforms. Journal of Petroleum Geology, 29, 41-52.

Esrafili-Dizaji, B., Rahimpour-Bonab, H., 2009. Effects of depositional and diagenetic characteristics on carbonate reservoir quality: a case study from the South Pars gas field in the Persian Gulf. Petroleum Geoscience, 15, 1-22.

Funayama, M., Hanor, J.S., 1995. Pore water salinity as a tool for evaluating reservoir continuity and fluid migration pathways in the Wilcox Group of Central Louisiana (abs.). American Association of Petroleum Geologists Bulletin, 79, 1558.

Gaynor, G.C., Sneider, R.M., 1992. Effective Pay Determination. In: Morton-Thompson, D., Woods, A.M. (eds.). Development Geology Reference Manual. American Association of Petroleum Geologists, Methods in Exploration Series, 10, 541pp.

Gomes, J.S., Riberio, M.T., Strohmenger, C.J., Negahban, S., Kalam, M.Z., 2008. Carbonate reservoir rock typing the link between geology and SCAL. Society of Petroleum Engineers (SPE), 118284.

Gunter, G.W., Finneran, J.M., Hartmann, D.J., Miller, J.D., 1997. Early determination of reservoir flow units using an integrated petrophysical method. Society of Petroleum Engineers (SPE) 38679, 373-380.

Hartmann, D.J., Beaumont, E.A., 1999. Predicting reservoir system quality and performance. In: Beaumont, E.A., Foster, N.H. (eds.). Exploring for oil and gas traps. American Association of Petroleum Geologists, Treatise of Petroleum Geology, Handbook of Petroleum Geology, 1150pp.

Hassan, H.M., 2007. Stylolite effect on geochemistry, porosity and permeability: comparison between a limestone and a dolomite sample from Khuff-B reservoir in Eastern Saudi Arabia. The Arabian Journal for Science and Engineering, 32(2A), 139-148.

Heydari, E., 2008. Tectonics versus eustatic control on supersequences of the Zagros Mountains of Iran. Tectonophysics, 451, 56-70.

Heydari, E., Wade, W.J., Hassanzadeh, J., 2001. Diagenetic origin of carbon and oxygen isotope compositions of PermianTriassic boundary strata. Sedimentary Geology, 143, 191197.

Insalaco, E., Virgone, A., Courme, B., Gaillot, J., Kamali, M., Moallemi, A., Lotfpour, M., Monibi, S., 2006. Upper Dalan Member and Kangan Formation between the Zagros Mountains and offshore Fars, Iran: Depositional system, biostratigraphy and stratigraphic architecture. GeoArabia, 11, 75-176.

Jolley, S.J., Fisher, Q.J., Ainworth, R.B., 2010. Reservoir compartmentalization: an introduction. In: Jolley, S.J., Fisher, Q.J., Ainworth, R.B., Vrolijk, P.J., Delisle, S. (eds.). Reservoir Compartmentalization. Geological Society, 347 (Special Publications), 362pp.

Kashfi, M.S., 1992. Geology of the Permian 'supergiant' gas 
reservoirs in the greater Persian Gulf area. . Journal of Petroleum Geology, 15, 465-480.

Kashfi, M.S., 2000. Greater Persian Gulf Permian-Triassic stratigraphic nomenclature requires study. Tulsa, Oil and Gas Journal, 6, 36-44.

Katz, A.J., Thompson, A.H., 1986. Quantitative Prediction of Permeability in Porous rock. Physical Review B, 34, 81798181.

Katz, A.J., Thompson, A.H., 1987. Prediction of Rock Electrical Conductivity from Mercury Injection Measurements. Journal of Geophysical Research, 92, 599-607.

Koepnick, R.B., 1987. Distribution and Permeability of StyloliteBearing Horizons within a Lower Cretaceous Carbonate Reservoir in the Middle East. Society of Petroleum Engineers (SPE) Formation Evaluation, 137-142.

Kolodzie, Jr.S., 1980. Analysis of pore throat size and use of the Waxman-Smits equation to determine OOIP in Spindle Field, Colorado. Society of Petroleum Engineers, SPE 9382.

Konert, G., Afifi, A.M., Al-Hajri, S.A., Groot, K.D., Al Naim, A.A., Droste, H.J., 2001. Paleozoic stratigraphy and hydrocarbon habitat of the Arabian Plate. American Association of Petroleum Geologists Memoir, 74, 483-515.

Konyuhov, A.I., Maleki, B., 2006. The Persian Gulf Basin: geological history, sedimentary formations, and petroleum potential. Lithology and Mineral Resources, 41, 344-361.

Lucia, F.J., 1992. Carbonate Reservoir Models: Facies, Diagenesis, and Flow Characterization. In: MortonThompson, D., Woods, A.M. (eds.). Development Geology Reference Manual. American Association of Petroleum Geologists Methods in Exploration Series, 10, 541pp.

Lucia, F.J., 1995. Rock-fabric/petrophysical classification of carbonate pore space for reservoir characterization. American Association of Petroleum Geologists Bulletin, 79(9), 12751300 .

Lucia, F.J., 2007. Carbonate reservoir characterization. Berlin Heidelberg, Springer-Verlag, 341pp.

Martin, A.J., Solomon, S.T., Hartmann, D.J., 1997. Characterization of petrophysical flow units in carbonate reservoirs. American Association of Petroleum Geologists Bulletin, 81, 734-759.

Mearns, E.W., McBride, J.J., 1999. Hydrocarbon filling and reservoir continuity of oil fields evaluated using $87 \mathrm{Sr} / 86 \mathrm{Sr}$ isotope ratio variations in formation water, with examples from the North Sea. Petroleum Geoscience, 5, 17-27.

Nelson, R.A., 1981. Significance of fracture sets associated with stylolite zones. American Association of Petroleum Geologists Bulletin, 65, 2417-2425.

Ortoleva, P.J., 1994. Basin Compartmentation: Definitions and Mechanisms. In: Ortoleva, P.J. (ed.). Basin Compartments and Seals. American Association of Petroleum Geologists Memoir, 61, 477pp.

Perotti, C.R., Carruba, S., Rinaldi, M., Bertozzi, G., Feltre, L., Rahimi, M., 2011. The Qatar-South Fars Arch Development (Arabian Platform, Persian Gulf): Insights from Seismic Interpretation and Analogue Modelling. In: Schattner, U. (ed.). New Frontiers in Tectonic Research - At the Midst of
Plate Convergence. Croatia, InTech, 352pp.

Pillevuit, A., 1993, Les Blocs Exotiques du Sultanat d'Oman: Evolution paléogéographique d'une marge passive flexurale. Lausanne, Université de Lausanne, Institut de Géologie et Paléontologie, 249pp.

Pittman, E.D., 1992. Relationship of porosity and permeability to various parameters derived from mercury injection-capillary pressure curves for sandstone. American Association of Petroleum Geologists Bulletin, 72(2), 191-198.

Pittman, E.D., Thomas, J.B., 1979. Some applications of scanning electron microscopy to the study of reservoir rock. Journal of Petroleum Technology, 31, 1375-1380.

Plint, D.A.G., Nummedal, D., 2000. The falling stage systems tract: recognition and importance in sequence stratigraphic analysis. In: Hunt, D., Gawthorpe, R.L. (eds.). Sedimentary Response to Forced Regression. Geological Society of London, 172(Special Publications), 1-17.

Posamentier, H.W., Allen, G.P., 1999. Siliciclastic sequence stratigraphy: concepts and applications. Society for Sedimentary Geology (SEPM), Concepts in Sedimentology and Paleontology, 7, 210pp.

Posamentier, H.W., Vail, P.R., 1988. Eustatic controls on clastic deposition II-Sequence and systems tract models. In: Wilgus, C.K., Posamentier, H., Van Wagoner, J., Hastings, B.S., Ross, C.A., Kendall, C.G.S.C. (eds.). Sea-level changes: an integrated approach. Tulsa (Oklahoma), Society of Economic Paleontologists and Mineralogists, 125-154.

Rahimpour-Bonab, H., 2007. A procedure for appraisal of a hydrocarbon reservoir continuity and quantification of its heterogeneity. Journal of Petroleum Science and Engineering, $58,1-12$.

Rahimpour-Bonab, H., Asadi-Eskandar, A., Sonei, A., 2009. Controls of Permian-Triassic Boundary over Reservoir Characteristics of South Pars Gas Field, Persian Gulf. Geological Journal, 44, 341-364.

Rahimpour-Bonab, H., Esrafili-Dizaji, B., Tavakoli, V., 2010. Dolomitization and anhydrite precipitation in Permo-Triassic carbonates at the South Pars gas Field, Offshore Iran: controls on reservoir quality. Journal of Petroleum Geology, 33, 43-66.

Rahimpour-Bonab, H., Mehrabi, H., Navidtalab, A., Izadi-Mazidi, E., 2012. Flow unit distribution and reservoir modeling in cretaceous carbonates of the Sarvak Formation, Abteymour Oilfield, Dezful embayment, SW IRAN. Journal of Petroleum Geology, 35, 1-24.

Saint-Marc, E., 1978. Arabian Peninsula. In: Moullade, M., Nairn, A.E.M. (eds.). The Phanerozoic geology of the world II: the Mesozoic. Amsterdam, Elsevier, 529pp.

Sharland, P.R., Archer, R., Casey, D.M., Davies, R.B., Hall, S.H., Heward, A.P., Horbury, A.D., Simmons, M.D., 2001. Arabian Plate sequence stratigraphy. Gulf PetroLink (Bahrain), GeoArabia, 2 (Special Publication), 371pp.

Slatt, R.M., Galloway, W.E., 1992. Geological Heterogeneities. In: Morton-Thompson, D., Woods, A.M. (eds.). Development Geology Reference Manual. American Association of Petroleum Geologists Memoir, Methods in Exploration Series, 10, 541pp. 
Smalley, P.C., Dodd, T.A., Stockden, I.L., Raheim, A., Mearns, E.W., 1995. Compositional heterogeneities in oil field formation waters: identifying them, using them. The Geochemistry of Reservoirs. Geological Society of London, 86 (Special Publications), 59-69.

Strohmenger, C.J., Always, R.H.S., Broomhall, R.W., Hulstrand, R.F., Al-Mansouri, A., Abdalla, A.A., Al-Aidarous, A., 2002. Sequence stratigraphy of the Khuff Formation comparing subsurface and outcrop data (Arabian Plate, UAE). 10th Abu Dhabi International Petroleum Exhibition and Conference, Society of Petroleum Engineers (SPE), 78535, 558-568.

Swanson, B.F., 1981. A Simple Correlation between Permeability and Mercury Capillary Pressures. Journal of Petroleum Technology, 33(12), 2498-2504.

Szabo, F., Kheradpir, A., 1978, Permian and Triassic stratigraphy, Zagros basin, South-West Iran. Journal of Petroleum Geology, $1,57-82$.

Tavakoli, V., Rahimpour-Bonab, H., 2012. Uranium depletion across Permian-Triassic Boundary in Persian Gulf and its implications for paleooceanic conditions. Palaeogeography, Palaeoclimatology, Palaeoecology, 350-352, 101-113.

Tavakoli, V., Rahimpour-Bonab, H., Esrafili-Dizaji, B., 2011. Diagenetic controlled reservoir quality of South Pars gas field, an integrated approach. Comptes Rendus Geoscience, 343, 55-71.

Tiab, D., Donaldson, E.C., 2004. Petrophysics: Theory and Practice of Measuring Reservoir Rock and Fluid Transport Properties. 2nd Edition, Gulf Professional Publishing, 926pp. Van Wagoner, J.C., Mitchum, R.M., Campion, K.M., Rahmanian,
V.D., 1990. Siliciclastic sequence stratigraphy in well logs, cores and outcrop. American Association of Petroleum Geologists, Methods in Exploration Series, 7, 55pp.

Walgenwitz, F., Burg, V., Levallois, B., 2001. High resolution salinity profiles in hydrocarbon reservoirs assessed from residual salt analysis of shaly intervals (abs.). Hot Springs (Virginia), 11th Goldschmidt Conference Abstracts, 3562.

Wardlaw, N.C., Taylor, R.P., 1976. Mercury capillary pressure curves and the interpretation of pore structures and capillary behavior in reservoir rocks. Bulletin of Canadian Petroleum Geology, 24, 225-262.

Wardlaw, N.C., McKellar, M., Li, Y., 1988. Pore and throat size distribution determined by mercury porosimetry and by direct observation. Carbonates and Evaporites, 3, 1-15.

Woule Ebongue, V., Jendrzejewski, N., Walgenwitz, F., Pineau, F., Javoy, M., 2005. Chlorine isotope residual salt analysis: a new tool to investigate formation waters form core analyses. American Association of Petroleum Geologists Bulletin, 89, 1005-1018.

Wonham, J.P., Cyrot, M., Nguyen, T., Louhouamou, J., Ruau, O., 2010. Integrated approach to geomodelling and dynamic simulation in a complex mixed siliciclastic-carbonate reservoir, N'Kossa field, Offshore Congo. In: Jolley, S.J., Fisher, Q.J., Ainworth, R.B., Vrolijk, P.J., Delisle, S. (eds.). Reservoir Compartmentalization. Geological Society Special Publication 347, 362pp.

Ziegler, M.A., 2001. Late Permian to Holocene Paleofacies Evolution of the Arabian Plate and Its Hydrocarbon Occurrences. GeoArabia, 6(3), 445-504.

Manuscript received March 2013;

revision accepted October 2014;

published Online February 2014. 


\section{ELECTRONIC APPENDIX}

TABLE I 1 The main characteristics of defined facies in the Upper Dalan-Lower Kangan intervals. The facies are grouped into four facies associations: peritidal, lagoon, shoal and off-shoal

\begin{tabular}{|c|c|c|c|c|c|c|c|c|c|}
\hline 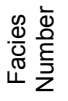 & $\begin{array}{l}\text { Facies } \\
\text { Name }\end{array}$ & & $\begin{array}{l}\text { Depositional } \\
\text { Environment }\end{array}$ & $\begin{array}{c}\text { Main } \\
\text { Lithology }\end{array}$ & Texture & $\begin{array}{l}\text { Fabrics } \\
\text { and } \\
\text { Structures }\end{array}$ & Allochems & $\begin{array}{l}\text { Grain } \\
\text { Size }\end{array}$ & Color \\
\hline $\mathrm{F} 1$ & $\begin{array}{c}\text { Nodular } \\
\text { Dolomudstone }\end{array}$ & & Supratidal & $\begin{array}{l}\text { Dolomite - } \\
\text { Anhydrite }\end{array}$ & Mudstone & Nodular & $\begin{array}{l}\text { Pelloid - } \\
\text { Bioclast }\end{array}$ & Calcilutite & $\begin{array}{c}\text { Brown - } \\
\text { Light }\end{array}$ \\
\hline $\mathrm{F} 2$ & $\begin{array}{c}\text { Dolomudstone } \\
\text { with Anhydrite } \\
\text { Crystals }\end{array}$ & & $\begin{array}{l}\text { Supratidal- } \\
\text { Intertidal }\end{array}$ & $\begin{array}{l}\text { Dolomite - } \\
\text { Anhydrite }\end{array}$ & Mudstone & Massive & $\begin{array}{l}\text { Ostracods - } \\
\text { Algal Filaments }\end{array}$ & Calcilutite & $\begin{array}{l}\text { Brown - } \\
\text { Yellow }\end{array}$ \\
\hline F3 & $\begin{array}{c}\text { Dolomudstone } \\
\text { (Dolomicrite) }\end{array}$ & $\begin{array}{l}\bar{\pi} \\
: \frac{0}{0} \\
0 \\
0 \\
0\end{array}$ & $\begin{array}{l}\text { Upper } \\
\text { Intertidal }\end{array}$ & Dolomite & Mudstone & $\begin{array}{l}\text { Massive and } \\
\text { Homogenous }\end{array}$ & ----- & Calcilutite & $\begin{array}{l}\text { Brown - } \\
\text { Yellow }\end{array}$ \\
\hline $\mathrm{F} 4$ & $\begin{array}{c}\text { Fenestral } \\
\text { Dolomudstone }\end{array}$ & & Intertidal & Dolomite & Mudstone & Fenestral & $\begin{array}{l}\text { Bioclast - } \\
\text { Pelloid }\end{array}$ & Calcilutite & $\begin{array}{l}\text { Dark } \\
\text { Brown }\end{array}$ \\
\hline F5 & $\begin{array}{l}\text { Stromatolite \& } \\
\text { Thrombolite } \\
\text { Boundstone }\end{array}$ & & $\begin{array}{l}\text { Intertidal - } \\
\text { Subtidal }\end{array}$ & $\begin{array}{l}\text { Dolomite - } \\
\text { Limestone }\end{array}$ & Boundstone & Massive & $\begin{array}{l}\text { Ostracods - } \\
\text { Foraminifera - } \\
\text { Pelloid }\end{array}$ & ----- & $\begin{array}{l}\text { Dark - } \\
\text { Brown }\end{array}$ \\
\hline F6 & $\begin{array}{c}\text { Pelloid- } \\
\text { Bioclast } \\
\text { Wackestone - } \\
\text { Packstone }\end{array}$ & & Lagoon & $\begin{array}{l}\text { Dolomite - } \\
\text { Limestone }\end{array}$ & $\begin{array}{c}\text { Wackestone } \\
- \\
\text { Packstone }\end{array}$ & Bioturbation & $\begin{array}{c}\text { Pelloid - } \\
\text { Bioclast - } \\
\text { Green Algae }\end{array}$ & $\begin{array}{l}\text { Calcilutite - } \\
\text { Calcarenite }\end{array}$ & $\begin{array}{l}\text { Dark } \\
\text { Brown }\end{array}$ \\
\hline $\mathrm{F} 7$ & $\begin{array}{l}\text { Ooid-Bioclast } \\
\text { Packstone - } \\
\text { Wackestone }\end{array}$ & & $\begin{array}{l}\text { Leeward } \\
\text { Shoal }\end{array}$ & Limestone & $\begin{array}{l}\text { Packstone - } \\
\text { Wackestone }\end{array}$ & Massive & Ooid-Bioclast & Calcarenite & $\begin{array}{l}\text { Light - } \\
\text { Yellow }\end{array}$ \\
\hline F8 & $\begin{array}{l}\text { Ooid-Bioclast } \\
\text { Grainstone - } \\
\text { Packstone }\end{array}$ & $\begin{array}{l}\overline{\widetilde{D}} \\
\frac{0}{\infty}\end{array}$ & $\begin{array}{l}\text { Central } \\
\text { Shoal }\end{array}$ & Limestone & $\begin{array}{l}\text { Grainstone - } \\
\text { Packstone }\end{array}$ & $\begin{array}{c}\text { Cross } \\
\text { Bedding } \\
\text { Grain Grading } \\
\text { \& Orientation }\end{array}$ & Ooid-Bioclast & Calcarenite & $\begin{array}{l}\text { Light - } \\
\text { Yellow }\end{array}$ \\
\hline F9 & $\begin{array}{c}\text { Coarse } \\
\text { Bioclast } \\
\text {-Intraclast } \\
\text { Grainstone }\end{array}$ & & $\begin{array}{l}\text { Seaward } \\
\text { Shoal }\end{array}$ & Limestone & Grainstone & $\begin{array}{c}\text { Cross } \\
\text { Bedding } \\
\text { Grain Grading } \\
\text { \& Orientation }\end{array}$ & $\begin{array}{l}\text { Bioclast - } \\
\text { Intraclast - } \\
\text { Ooid-Pelloid }\end{array}$ & $\begin{array}{l}\text { Calcarenite } \\
\text { Calcirudite }\end{array}$ & $\begin{array}{l}\text { Light } \\
\text { Yellow- } \\
\text { Brown }\end{array}$ \\
\hline F10 & $\begin{array}{c}\text { Bioclast } \\
\text { Wackestone - } \\
\text { Mudstone }\end{array}$ & $\begin{array}{l}\bar{\pi} \\
\stackrel{0}{\infty} \\
\text { की }\end{array}$ & Mid Ramp & Limestone & $\begin{array}{c}\text { Wackestone } \\
\text { - } \\
\text { Mudstone }\end{array}$ & $\begin{array}{c}\text { Massive and } \\
\text { Poor } \\
\text { Lamination }\end{array}$ & Bioclast & $\begin{array}{c}\text { Calcarenite } \\
\text { Calcilutite }\end{array}$ & Brown \\
\hline F11 & $\begin{array}{l}\text { Fine Bioclast } \\
\text { Mudstone }\end{array}$ & $L^{4}$ & Outer Ramp & Limestone & Mudstone & Lamination & Bioclast & Calcilutite & $\begin{array}{l}\text { Dark } \\
\text { Brown }\end{array}$ \\
\hline
\end{tabular}


TABLE I 1 Characteristics of Flow Units (FU) in the South Pars and Golshan gas fields defined the using SMLP method. Three Intra Reservoir Barriers (IRBs) units were defected. The main petrophysical properties of the defined flow units are the means of porosity $\left(\Phi_{m}\right)$, permeability $\left(K_{m}\right)$ and $R_{35}$, the percentage of flow and the storage capacity (Kh\% and $\Phi \mathrm{h} \%$ ). In the studied wells, each flow unit has overall sedimentological and petrophysical similarity.

\begin{tabular}{|c|c|c|c|c|c|c|c|c|}
\hline $\begin{array}{l}\text { Flow } \\
\text { Unit }\end{array}$ & Well & Main Lithology & Dominant Facies & $\begin{array}{l}\Phi_{m} \\
(\%)\end{array}$ & $\begin{array}{c}\mathrm{K}_{\mathrm{m}} \\
(\mathrm{mD})\end{array}$ & $\begin{array}{l}R_{35 m} \\
(\mu \mathrm{m})\end{array}$ & $\mathrm{Kh} \%$ & $\Phi \mathrm{h} \%$ \\
\hline \multirow{6}{*}{1} & $\mathrm{G} 1$ & Dolostone - Anhydrite & Peritidal - Shoal & 0.7 & 0.64 & 1.2 & 0.74 & 0.67 \\
\hline & SP1 & Anhydrite - Dolo - Limestone & Shoal - Peritidal - Lagoon & 1.71 & 0.45 & 0.84 & 0.80 & 1.59 \\
\hline & SP2 & Dolostone - Anhydrite & Shoal - Lagoon & 5.20 & 1.84 & 0.47 & 0.20 & 0.80 \\
\hline & SP3 & Dolostone - Anhydrite & Shoal - Lagoon & 2.64 & 0.51 & 1.10 & 0.45 & 3.21 \\
\hline & SP4 & Anhydrite - Dolostone & Peritidal & 1.14 & 0.06 & 1.00 & 0.13 & 0.80 \\
\hline & SP5 & Anhydrite - Dolostone & Peritidal & 2.00 & 0.03 & 0.71 & 0.02 & 1.96 \\
\hline \multirow{9}{*}{2} & SP6 & Anhydrite - Dolostone & Peritidal - Shoal & 4.13 & 0.27 & 0.73 & 0.96 & 5.67 \\
\hline & $\mathrm{G} 1$ & Dolostone - Limestone & Lagoon - Peritidal - Shoal & 4.36 & 34.46 & 11.30 & 17.67 & 2.77 \\
\hline & SP1 & Limestone & Shoal - Off shoal - Lagoon & 5.48 & 2.58 & 0.84 & 2.24 & 3.98 \\
\hline & SP2 & Limestone - Dolostone & Shoal - Off shoal & 13.05 & 131.58 & 6.60 & 36.08 & 8.67 \\
\hline & SP3 & Dolostone & Shoal & 13.37 & 115.15 & 5.16 & 60.93 & 8.74 \\
\hline & SP4 & Limestone - Dolostone & Shoal - Lagoon & 13.50 & 18.46 & 2.32 & 34.56 & 7.85 \\
\hline & SP5 & Limestone - Dolostone & Shoal - Off shoal & 19.39 & 209.55 & 5.80 & 70.00 & 9.29 \\
\hline & SP6 & Limestone - Dolostone & Shoal - Off shoal & 14.52 & 20.13 & 2.46 & 30.88 & 7.53 \\
\hline & $\mathrm{G} 1$ & Limestone & Peritidal - Lagoon & 3.00 & 8.68 & 4.56 & 6.64 & 4.34 \\
\hline \multirow{5}{*}{3} & SP1 & Limestone & Shoal & 10.71 & 9.50 & 1.71 & 6.03 & 6.28 \\
\hline & SP2 & Limestone & Shoal - Peritidal & 10.11 & 5.00 & 1.17 & 1.30 & 6.45 \\
\hline & SP3 & Limestone & Shoal & 7.80 & 1.89 & 1.34 & 1.83 & 6.42 \\
\hline & SP4 & Limestone & Shoal - Off shoal & 10.24 & 0.92 & 0.71 & 4.20 & 13.7 \\
\hline & SP5 & Limestone & Shoal - Off shoal & 11.83 & 2.94 & 0.74 & 1.58 & 8.46 \\
\hline \multirow{9}{*}{4} & SP6 & Limestone & Shoal - Off shoal & 10.24 & 0.92 & 0.71 & 3.08 & 11.19 \\
\hline & $\mathrm{G} 1$ & Limestone & Lagoon - Shoal - Peritidal & 1.26 & 0.06 & 0.71 & 0.05 & 0.94 \\
\hline & SP1 & Limestone - Anhydrite & Off shoal - Shoal & 2.23 & 0.07 & 0.59 & 0.04 & 0.98 \\
\hline & SP2 & Limestone - Anhydrite & Shoal - Lagoon & 1.68 & 0.38 & 0.79 & 0.02 & 0.17 \\
\hline & SP3 & Limestone & Off shoal - Shoal & 1.54 & 0.44 & 0.75 & 0.13 & 0.57 \\
\hline & SP4 & Limestone - Anhydrite & Un-cored & 1.15 & 0.06 & 0.80 & 0.05 & 0.32 \\
\hline & SP5 & Limestone - Anhydrite & Off shoal - Shoal & 2.25 & 0.04 & 0.55 & 0.01 & 1.18 \\
\hline & SP6 & Dolo - Limestone - Anhydrite & Peritidal & 2.75 & 0.08 & 0.86 & 0.08 & 0.90 \\
\hline & $\mathrm{G} 1$ & Dolo - Limestone - Anhydrite & Peritidal - Lagoon - Shoal & 5.48 & 3.59 & 1.19 & 14.55 & 23.54 \\
\hline \multirow{5}{*}{5} & SP1 & Dolostone & Shoal - Lagoon & 9.83 & 23.54 & 2.40 & 63.97 & 16.53 \\
\hline & SP2 & Dolostone - Limestone & Shoal - Lagoon - Peritidal & 12.85 & 70.93 & 4.96 & 30.30 & 15.49 \\
\hline & SP3 & Dolostone & Shoal - Lagoon & 9.95 & 10.02 & 1.31 & 8.51 & 8.00 \\
\hline & SP4 & Dolostone & Shoal - Lagoon & 10.62 & 3.61 & 1.05 & 11.26 & 12.72 \\
\hline & SP5 & Dolostone & Shoal - Lagoon & 13.62 & 9.39 & 1.56 & 4.66 & 12.61 \\
\hline \multirow{9}{*}{6} & SP6 & Dolostone & Shoal - Lagoon & 11.03 & 3.97 & 1.02 & 11.66 & 14.78 \\
\hline & $\mathrm{G} 1$ & Limestone & Shoal - Peritidal & 9.65 & 1.44 & 0.83 & 2.39 & 11.74 \\
\hline & SP1 & Dolostone - Anhydrite & Un-cored & 1.96 & 0.23 & 0.73 & 0.47 & 3.37 \\
\hline & SP2 & Dolostone - Anhydrite & Off shoal - Shoal - Lagoon & 5.31 & 9.77 & 29.14 & 16.92 & 8.1 \\
\hline & SP3 & Dolostone - Anhydrite & Shoal - Lagoon - Peritidal & 3.00 & 0.69 & 1.51 & 0.80 & 5.44 \\
\hline & SP4 & Dolostone - Anhydrite & Lagoon - Shoal & 2.63 & 0.46 & 1.16 & 2.43 & 5.51 \\
\hline & SP5 & Dolostone - Anhydrite & Lagoon - Shoal - Peritidal & 2.81 & 0.50 & 1.32 & 0.50 & 5.07 \\
\hline & SP6 & Dolostone - Anhydrite & Shoal - Peritidal - Lagoon & 2.57 & 0.45 & 1.19 & 2.38 & 4.96 \\
\hline & $\mathrm{G} 1$ & Limestone & Off shoal - Shoal & 4.22 & 0.57 & 1.00 & 0.82 & 3.15 \\
\hline \multirow{5}{*}{7} & SP1 & Limestone - Anhydrite & Un-cored & 1.00 & 0.02 & 0.56 & 0.05 & 1.59 \\
\hline & SP2 & Limestone - Anhydrite & Un-cored & 3.13 & 0.33 & 1.12 & 0.18 & 4.35 \\
\hline & SP3 & Dolostone - Anhydrite & Lagoon - Peritidal - Shoal & 1.42 & 0.07 & 1.42 & 0.13 & 3.40 \\
\hline & SP4 & Dolostone - Anhydrite & Lagoon - Peritidal & 0.91 & 0.25 & 0.48 & 0.75 & 1.16 \\
\hline & SP5 & Dolostone - Anhydrite & $\begin{array}{c}\text { Shoal - Off shoal - Lagoon - } \\
\text { Daritinal }\end{array}$ & 2.04 & 0.08 & 1.12 & 0.10 & 4.60 \\
\hline
\end{tabular}

